Document downloaded from:

http://hdl.handle.net/10251/162858

This paper must be cited as:

Gonzalez-Camejo, J.; Aparicio, S.; Jiménez Benítez, AL.; Paches Giner, MAV.; Ruano, MV.; Borrás, L.; Barat, R.... (2020). Improving membrane photobioreactor performance by reducing light path: operating conditions and key performance indicators. Water Research. 172:1-10.

https://doi.org/10.1016/j.watres.2020.115518

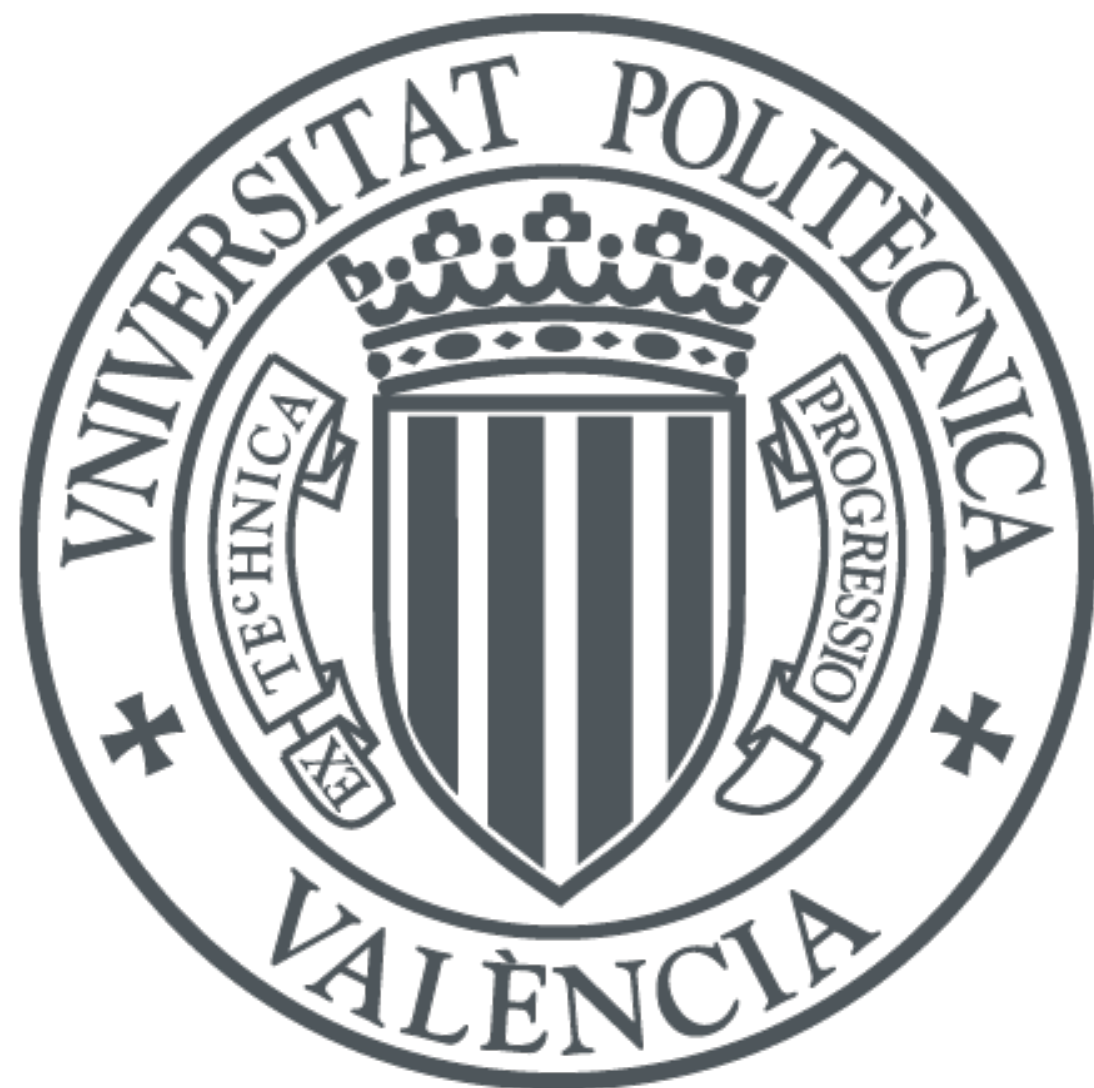

The final publication is available at

https://doi.org/10.1016/j.watres.2020.115518

Copyright Elsevier

Additional Information

CIWA Publishing 2020. The definitive peer-reviewed and edited version of this article is published in Water Research, Volume 172, 1 April 2020, 115518 https://doi.org/10.1016/j.watres.2020.115518 and is available at www.iwapublishing.com. 


\title{
Improving membrane photobioreactor performance by reducing light path: operating conditions and key performance indicators
}

\author{
J. González-Camejo ${ }^{1 *}$, S. Aparicioº ${ }^{2}$ A. Jiménez-Benítez ${ }^{1}$, M. Pachés ${ }^{1}$, M.V. Ruano², L. \\ Borrás $^{2}$, R. Barat ${ }^{1}$ and A. Seco ${ }^{2}$.
}

${ }^{1}$ CALAGUA - Unidad Mixta UV-UPV, Institut Universitari d'Investigació d'Enginyeria de l'Aigua i Medi Ambient-IIAMA, Universitat Politècnica de València, Camí de Vera s/n, 46022 Valencia, Spain.

${ }^{2}$ CALAGUA - Unidad Mixta UV-UPV, Departament d'Enginyeria Química, Universitat de València, Avinguda de la Universitat s/n, 46100 Burjassot, Valencia, Spain.

*Corresponding author: jogonca4@upv.es (J. González-Camejo)

\begin{abstract}
Microalgae cultivation has been receiving increasing interest in wastewater remediation due to their ability to assimilate nutrients present in wastewater streams. In this respect, cultivating microalgae in membrane photobioreactors (MPBRs) allows decoupling the solid retention time (SRT) from the hydraulic retention time (HRT), which enables to increase the nutrient load to the photobioreactors (PBRs) while avoiding the wash out of the microalgae biomass. The reduction of the PBR light path from 25 to $10 \mathrm{~cm}$ increased the nitrogen and phosphorus recovery rates, microalgae biomass productivity and photosynthetic efficiency by 150, 103, 194 and 67\%, respectively. The areal biomass productivity $(\mathrm{aBP})$ also increased when the light path was reduced, reflecting the better use of light in the $10-\mathrm{cm}$ MPBR plant. The capital and operating operational expenditures (CAPEX and OPEX) of the 10-cm MPBR plant were also reduced by 27 and $49 \%$, respectively. Discharge limits were met when the $10-\mathrm{cm}$ MPBR plant was operated at SRTs of 3-4.5 d and HRTs of 1.25-1.5 d. At these SRT/HRT ranges, the
\end{abstract}


process could be operated without a high fouling propensity with gross permeate flux $\left(\mathrm{J}_{20}\right)$ of $15 \mathrm{LMH}$ and specific gas demand $\left(\mathrm{SGD}_{\mathrm{p}}\right)$ between 16 and $20 \mathrm{Nm}^{3}$ air $\mathrm{m}^{-3}$ permeate, which highlights the potential of membrane filtration in MPBRs.

When the continuous operation of the MPBR plant was evaluated, an optical density of $680 \mathrm{~nm}(\mathrm{OD} 680)$ and soluble chemical oxygen demand (sCOD) were found to be good indicators of microalgae cell and algal organic matter (AOM) concentrations, while dissolved oxygen appeared to be directly related to MPBR performance. Nitrite and nitrate $\left(\mathrm{NO}_{\mathrm{x}}\right)$ concentration and the soluble chemical oxygen demand:volatile suspended solids ratio (sCOD:VSS) were used as indicators of nitrifying bacteria activity and the stress on the culture, respectively. These parameters were inversely related to nitrogen recovery rates and biomass productivity and could thus help to prevent possible culture deterioration.

\section{Introduction}

Microalgae cultivation has gained great interest within scientific community due to their multiple applications: i) animal and human food industry; ii) production of valuable compounds (cosmetics, pharmaceuticals, carotenoids, etc.); iii) production of biofuels such as biodiesel, biogas and bioethanol; iv) fertilisers (or bio-stimulants) for the agricultural industry; and v) bioremediation of wastewater streams (Seco et al., 2018; $\mathrm{Xu}$ et al., 2019). It should be considered that the final application potential of the microalgae biomass depends on the biomass production process (Garrido-Cárdenas et al., 2018). In this respect, microalgae biomass cultivated in wastewater media can be used for non-human related applications such as energy (bio-diesel, bio-ethanol, biohydrogen, etc.) and bio-fertiliser (bio-stimulant) production. However, outdoor microalgae cultivation is still challenging due to the lower microalgae growth rates than 
other microorganisms such as heterotrophic bacteria. This means outdoor photobioreactors (PBRs) must be operated at long hydraulic retention times (HRTs) of around 3.5-10 d (Arbib et al., 2017; Romero-Villegas et al., 2018), which implies high cultivation area needs (Xu et al., 2019).

As a solution, membrane separation of microalgae from permeate allows operations at different solids retention (SRT) and hydraulic retention times (HRT). SRT is directly related to biomass production, while HRT controls the nutrient loading rate (GonzálezCamejo et al., 2019a). Decoupling the SRT and HRT can therefore increase the nutrient load while biomass washout is avoided (Gao et al., 2019), enhancing microalgae performance. On the other hand, operating at too low HRT values can be detrimental for nutrient recovery efficiency, since the microalgae may not be able to absorb all the nutrient content in the wastewater, therefore losing significant amounts of nitrogen and phosphorus with the effluent (Judd et al., 2015) and not meeting the legal requirements. This means that HRT and SRT of each microalgae cultivation system must be optimised.

MPBRs can also obtain high quality effluents in terms of suspended solids and pathogens, since they efficiently separate the microalgae and pollutants present in the culture from water (Gao et al., 2019), providing a source of reclaimed water (GonzálezCamejo et al., 2019a). Nevertheless, improvement of membrane operation aims at reducing membrane fouling, as it considerably affects the economic sustainability of MPBR technology (Seco et al., 2018). Fouling mainly consists of partial block of membrane pores and cake-layer formation due to accumulation of microalgae biomass and other substances such as algal organic matter (AOM) (Liu et al., 2017; Luo et al., 2019). AOM is commonly released by microalgae activity (Henderson et al., 2008), but its production is intensified under microalgae stress conditions (Lee et al., 2018). 
Hence, operating conditions that make microalgae produce lower amounts of AOM need to be found.

Another controversial aspect of microalgae technology is the light available to the PBRs which is the main factor limiting microalgae growth (Barceló-Villalobos et al., 2019). Dense microalgae cultures absorb the light irradiance along the PBR light path (Huang et al., 2019), which means low photosynthetic efficiencies of $1.5-2 \%$ are usually found in large-scale PBRs (Nwoba et al., 2019). In this respect, the PBR light path plays an important role in photosynthetic efficiency, since light is attenuated as it passes through the culture (Fernández-Sevilla et al., 2018). Several studies have assessed the effect of light path on microalgae-based wastewater reactors, although the results are controversial (Table 1). Moreover, some of these results have been evaluated by simulation (Fernández et al., 2016; Huang et al., 2019; Slegers et al., 2011). The optimum light path therefore needs to be defined separately in each microalgae cultivation system.

Table 1. Optimal light path for outdoor microalgae cultivation systems.

\begin{tabular}{ccc}
\hline Lp (cm) & Type of reactor & Reference \\
\hline 30 & Raceway pond & Arbib et al. (2017) \\
\hline 5 & Raceway pond & Fernández et al. (2016) \\
\hline $10-15$ & Cylindrical PBR & Huang et al. (2019)* \\
\hline $2-5$ & Flat-panel PBR & Slegers et al. (2011)* \\
\hline
\end{tabular}

Lp: Light path; PBR: photobioreactor.

"Results obtained by simulation 
In order to improve the implementation of microalgae cultivation systems, they have to be optimally operated to obtain maximum yields. A previous study on optimising an MPBR plant with 25-cm-wide PBRs obtained the best performance with a SRT and HRT of 4.5 and 3.5 d, respectively (González-Camejo et al., 2019a). However, as these 25-cm PBRs were found to be highly light-limited, their light path was reduced to 10 $\mathrm{cm}$. The goal of this study was thus to assess the effect of the PBR light path on microalgae performance in an outdoor $10-\mathrm{cm}$ MPBR plant that treats effluent from an AnMBR system. The following key performance indicators (KPI) were evaluated during the continuous operation of an outdoor membrane photobioreactor: nutrient recovery rates, biomass productivity, OD680, sCOD:VSS, total eukaryotic cells (TEC), dissolved oxygen (DO) and $\mathrm{NO}_{\mathrm{x}}$ concentrations.

\section{Materials and methods}

\subsection{Microalgae and substrate}

Indigenous microalgae were obtained from a mixed culture used in previous work (González-Camejo et al., 2019a), mainly consisting of eukaryotic microalgae dominated by Chlorella (> 95\% of TEC). Green microalgae Scenedesmus, cyanobacteria, nitrifying and heterotrophic bacteria were also present in low concentrations.

The substrate consisted of the nutrient-rich effluent from an AnMBR plant that treated real effluent from a primary settler (described in Seco et al. (2018)). The average characteristics of this substrate were nitrogen concentration of $45.0 \pm 9.1 \mathrm{mg} \mathrm{N} \cdot \mathrm{L}^{-1}$ and phosphorus concentration of $4.7 \pm 1.3 \mathrm{mg} \mathrm{P} \cdot \mathrm{L}^{-1}$, which meant an $\mathrm{N}: \mathrm{P}$ molar ratio of 22.7 \pm 6.8. Chemical oxygen demand (COD) concentration reached $71 \pm 35 \mathrm{mg} \mathrm{COD} \cdot \mathrm{L}^{-1}$, while biochemical oxygen demand (BOD) only accounted for $27 \pm 2 \mathrm{mg} \mathrm{COD} \cdot \mathrm{L}^{-1}$, 
which boosted autotrophic metabolism of microalgae (Ferreira et al., 2019; Razzak et al., 2017).

\subsection{MPBR pilot plant}

The outdoor MPBR plant was operated in the Carraixet WWTP (39³0'04.0'’ $\mathrm{N}$ $0^{\circ} 20^{\prime} 00.1^{\prime}$ 'W, Valencia, Spain). It mainly consisted of two flat-panel PBRs connected to a membrane tank (MT) (Figure 1). The PBRs had a surface area of $2.3 \mathrm{~m}^{2}(1.15 \mathrm{x} 2$ m). In a previous study, these PBRs had a light path of $25 \mathrm{~cm}$ (González-Camejo et al., 2019a), but this was reduced to $10 \mathrm{~cm}$ for the present study in order to try to increase the light use efficiency while maintaining high treatment capacity. The PBRs were continuously air-stirred making the culture be well-mixed and maintaining oxygen concentrations over the saturation. The PBR inner surfaces were brushed three times a week to avoid biofouling inside the reactors, which can block the light flux. Two (one in each PBR) $\mathrm{pH}$ sensors (pHD sc DPD1R1, Hach Lange) and two (one in each PBR) dissolved oxygen-temperature sensors (LDO sc LXV416.99.20001, Hach Lange) were installed inside the PBRs. Moreover, one irradiation sensor (Apogee Quantum SQ-200) was set on the PBR2 surface to measure the photosynthetically active radiation (PAR). Both PBRs had an additional artificial white light source consisting of twelve LED lamps (Unique Led IP65 WS-TP4S-40W-ME) installed at the back of the PBRs offering a continuous light irradiance of $300 \mu \mathrm{E} \cdot \mathrm{m}^{-2} \cdot \mathrm{s}^{-1}$ measured on the PBR surface. Culture temperature was controlled by a cooling device equipped with a thermostat (Daikin Inverter R410A). Cooled water was supplied to the MPBR plant by $20-\mathrm{m}$ long coiled pipe (set inside each PBR). The chosen temperature set-point was $16{ }^{\circ} \mathrm{C}$. The cooling fluid was pumped to the PBRs by opening an electrovalve whenever the temperature went over $25^{\circ} \mathrm{C} . \mathrm{CO}_{2}$ was injected into the air system to maintain $\mathrm{pH}$ values at $7.5 \pm$ 
0.3. In this way, ammonia volatilisation and phosphorous precipitation were effectively minimised and carbon-replete conditions were ensured.

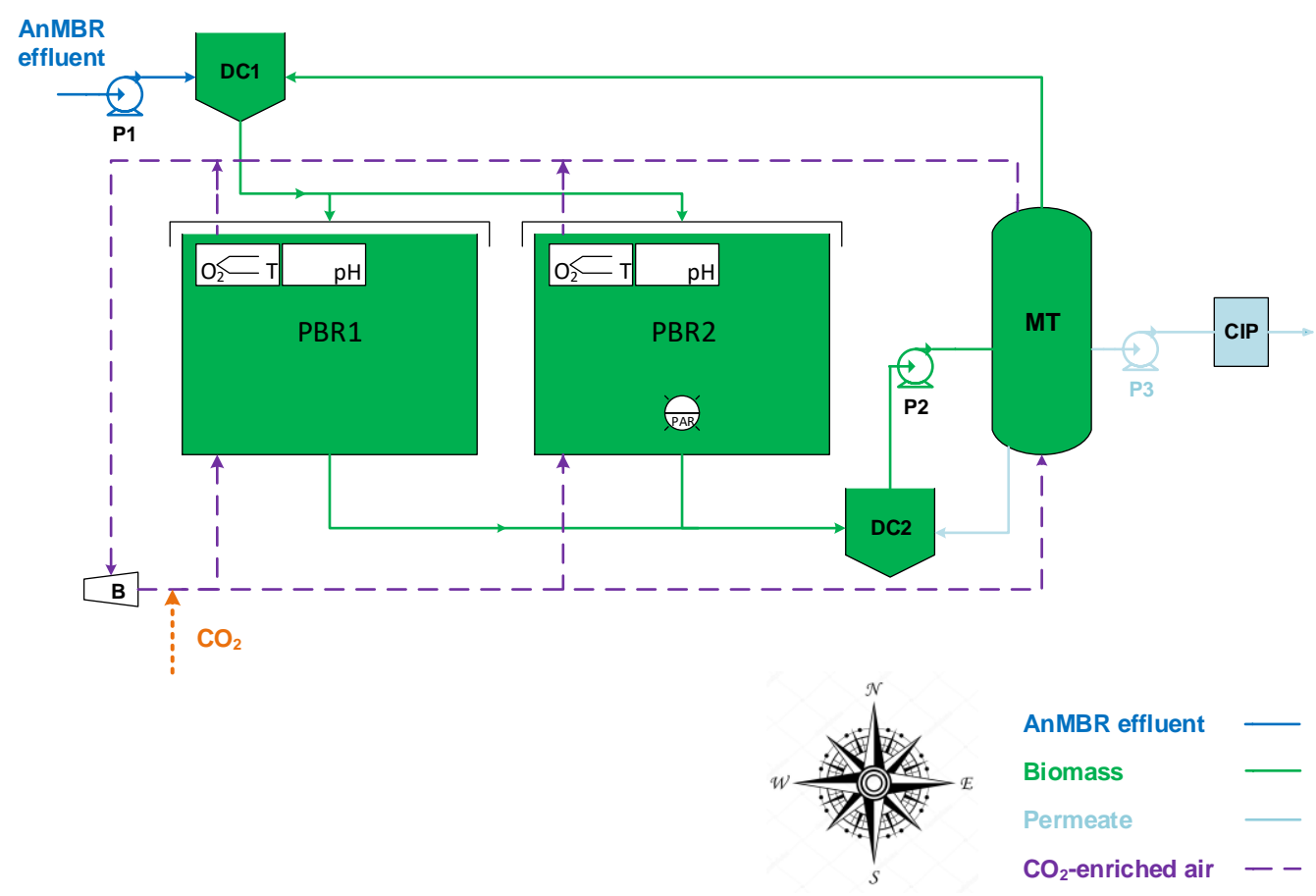

Figure 1: Lay-out of the membrane photobioreactor (MPBR) plant. PBR:

photobioreactor; MT: membrane tank; P: pump; DC: distribution chamber; B: blower; CIP: clean-in-place-tank; $\mathrm{O}_{2}-\mathrm{T}$ : dissolved oxygen-temperature sensor; $\mathrm{pH}$ : $\mathrm{pH}$ sensor.

The MT had a total working volume of $14 \mathrm{~L}$ and a filtration area of $3.4 \mathrm{~m}^{2}$. It consisted of one hollow-fibre ultrafiltration membrane bundle extracted from an industrial-scale membrane unit (PURON ${ }^{\circledR}$ Koch Membrane Systems (PUR-PSH31), $0.03 \mu \mathrm{m}$ pores). Air was introduced at the base of the MT to reduce membrane fouling by membrane scouring. The membrane operating mode followed a sequence of 300-s basic F-R cycle (250 s filtration and $50 \mathrm{~s}$ relaxation), $40 \mathrm{~s}$ of back-flush every $10 \mathrm{~F}-\mathrm{R}$ cycles, $60 \mathrm{~s}$ of ventilation every $20 \mathrm{~F}-\mathrm{R}$ cycles and $60 \mathrm{~s}$ of degasification every $50 \mathrm{~F}-\mathrm{R}$ cycles. The gross $20^{\circ} \mathrm{C}$-standardised transmembrane flux $\left(\mathrm{J}_{20}\right)$ was kept at $15-26 \mathrm{LMH}$. The average 
specific gas demand per volume of produced permeate $\left(\mathrm{SGD}_{\mathrm{P}}\right)$ was around $16-20 \mathrm{Nm}^{3}$ of gas per $\mathrm{m}^{3}$ of permeate for two operating specific gas demands per $\mathrm{m}^{2}$ of membrane $\left(\mathrm{SGD}_{\mathrm{m}}\right)$, i.e. 0.3 and $0.4 \mathrm{Nm}^{3} \cdot \mathrm{m}^{-2} \cdot \mathrm{h}^{-1}$, respectively.

Further details of the automation of the MPBR plant can be found in González-Camejo et al. (2019a).

\subsubsection{MPBR plant operation}

The present study was divided in two sets of experiments: the first consisted of evaluating the light path effect on microalgae performance by comparing the results obtained for two different MPBR light paths: a 25-cm-wide MPBR plant (an extensive description of the operating conditions in this plant can be found in González-Camejo et al. (2019a)) and a 10-cm-wide MPBR plant. Both plants were operated at a SRT of 4.5 $\mathrm{d}$ and an HRT of $1.5 \mathrm{~d}$. Allylthiourea (ATU) was added to maintain a concentration of 5 $\mathrm{mg} \cdot \mathrm{L}^{-1}$, so that nitrification was inhibited in both cases and the competition between microalgae and the growth of ammonium oxidising bacteria (AOB) for ammonium uptake was avoided (González-Camejo et al., 2019a). The microalgae culture was dominated by Chlorella in both MPBR plants.

The second set of experiments consisted of the continuous operation of the $10-\mathrm{cm}$ MPBR plant without nitrification inhibition. The aim was to determine the optimal operating conditions of this $10-\mathrm{cm}$ MPBR plant and to assess the process KPI. Based on previous studies (González-Camejo et al., 2019a) and the growth rates obtained during the batch stages of the cultivation process (Appendix A), SRT and HRT were modified in the range of 2-4.5 $\mathrm{d}$ and 1-1.5 $\mathrm{d}$, respectively, in 3 different experimental periods (Table 2). The duration of each period was based on the relative stability of the microalgae culture characteristics. Period 1 was carried out between January and 
February 2017; Period 2 was developed in March-April 2017; while Period 3 was operated during August and September 2017. The pseudo-steady state in Periods 1, 2 and 3 was established when having VSS concentrations did not significantly vary (González-Camejo et al., 2019a). Solar photosynthetically active radiation (PAR) varied in the range $1200-1560 \mu \mathrm{mol} \cdot \mathrm{m}^{-2} \cdot \mathrm{s}^{-1}$ (Table 2). All periods were preceded by chemical cleaning of the membranes and a start-up phase (as explained in detail in GonzálezCamejo et al. (2019a)).

Table 2. Operation and outdoor conditions of each operation period.

\begin{tabular}{cccccccc}
\hline Period & $\begin{array}{c}\text { Days of } \\
\text { operation }\end{array}$ & $\begin{array}{c}\text { Solar PAR } \\
\left(\boldsymbol{\mu m o l} \cdot \mathbf{m}^{-2} \cdot \mathbf{s}^{-\mathbf{1}}\right)\end{array}$ & $\begin{array}{c}\text { Temperature } \\
\left({ }^{\mathbf{0}} \mathbf{C}\right)\end{array}$ & $\begin{array}{c}\text { BRT } \\
(\mathbf{d})\end{array}$ & $\begin{array}{c}\text { HRT } \\
(\mathbf{d})\end{array}$ & $\begin{array}{c}\text { NLR } \\
\left(\mathbf{g ~ N} \cdot \mathbf{d}^{-\mathbf{1}}\right)\end{array}$ & $\begin{array}{c}\text { PLR } \\
\left(\mathbf{g ~ P} \cdot \mathbf{d}^{-\mathbf{1}}\right)\end{array}$ \\
\hline $\mathbf{1}$ & 35 & $281 \pm 119$ & $23.9 \pm 1.7$ & 4.5 & 1.5 & $12.6 \pm 3.0$ & $1.2 \pm 0.5$ \\
$\mathbf{2}$ & 25 & $344 \pm 46$ & $24.2 \pm 1.7$ & 3 & 1.5 & $16.9 \pm 3.5$ & $1.8 \pm 0.4$ \\
$\mathbf{3}$ & 25 & $266 \pm 72$ & $25.5 \pm 1.2$ & 3 & 1.25 & $15.1 \pm 1.9$ & $1.5 \pm 0.3$ \\
\hline
\end{tabular}

\subsection{Sampling and analytical methods}

Grab samples of MPBR and AnMBR effluents, as well as of the microalgae culture, were collected in duplicate three times a week. Ammonium $\left(\mathrm{NH}_{4}\right)$, nitrite $\left(\mathrm{NO}_{2}\right)$, nitrate $\left(\mathrm{NO}_{3}\right)$ and phosphate $\left(\mathrm{PO}_{4}\right)$ were analysed according to Standard Methods (APHA, 2012): 4500-NH3-G, 4500-NO2-B, 4500-NO3-H and 4500-P-F, respectively, using an automatic analyser (Smartchem 200, WestcoScientific Instruments, Westco). Volatile suspended solids (VSS) concentration was also measured in duplicate, according to method 2540 E of the Standard Methods (APHA, 2012). 
Total and soluble chemical oxygen demand (COD and sCOD) were tested once a week in duplicate according to Standard Methods (APHA, 2012) 5220-COD-C and 522COD-D, respectively.

Total nitrogen $(\mathrm{tN})$ concentration of the culture was measured by colorimetric analysis using the nitrogen total cell test kit (Merckoquant 1.14537.001, Merck, Germany) according to the manufacturer's instructions. Total phosphorus (tP) concentration was also measured in culture after total digestion at $150{ }^{\circ} \mathrm{C}$ for two hours, followed by orthophosphate determination according to Standard Methods, 4500-P-F, (APHA, 2012), using an automatic analyser (Smartchem 200, WestcoScientific Instruments, Westco).

The OD680 and maximum quantum yield of photosystem II $\left(\mathrm{F}_{\mathrm{v}} / \mathrm{F}_{\mathrm{m}}\right)$ were measured insitu with a portable fluorometer AquaPen-C AP-C 100 (Photon Systems Instruments). Before measuring the $\mathrm{F}_{\mathrm{v}} / \mathrm{F}_{\mathrm{m}}$, the samples remained in the dark for ten minutes to become dark-adapted.

The wavelength spectrum (400-700 nm) was recorded by a spectrophotometer (Spectroquant ${ }^{\circledR}$ Pharo 100, Merck, Germany).

Total eukaryotic cells (TEC) were counted in duplicate twice a week. $50 \mu \mathrm{L}$ of the sample were filtered through $0.2 \mu \mathrm{m}$ membranes (Millipore GTTP). Cell counts were performed by epifluorescence microscopy on a Leica DM2500, using the 100x-oil immersion lens. A minimum of 300 cells were counted, with an error of less than $20 \%$.

\subsection{Calculations}

Nitrogen recovery rate $(\mathrm{NRR})\left(\mathrm{mg} \mathrm{N} \cdot \mathrm{L}^{-1} \cdot \mathrm{d}^{-1}\right)$ and phosphorus recovery rate $(\mathrm{PRR})(\mathrm{mg}$ $\mathrm{P} \cdot \mathrm{L}^{-1} \cdot \mathrm{d}^{-1}$ ) were calculated as described in Eq. 1 and Eq. 2, respectively:

$$
\mathrm{NRR}=\frac{F \cdot\left(N_{i n f}-N_{e}\right)}{\mathrm{V}_{M P B R}} \quad[\mathrm{Eq} .1]
$$


$\operatorname{PRR}=\frac{F \cdot\left(P_{\text {inf }}-P_{e}\right)}{\mathrm{V}_{M P B R}}$

[Eq. 2]

where $\mathrm{F}$ is the treatment flow rate $\left(\mathrm{m}^{3} \cdot \mathrm{d}^{-1}\right) ; \mathrm{N}_{\text {inf }}$ is the influent nitrogen concentration $\left(\mathrm{mg} \mathrm{N} \cdot \mathrm{L}^{-1}\right) ; \mathrm{N}_{\mathrm{e}}$ is the effluent nitrogen concentration $\left(\mathrm{mg} \mathrm{N} \cdot \mathrm{L}^{-1}\right)$; $\mathrm{V}_{\mathrm{MPBR}}$ is the volume of the culture in the MPBR plant $\left(\mathrm{m}^{3}\right)$; $\mathrm{P}_{\text {inf }}$ is the influent phosphorus concentration $(\mathrm{mg}$ $\left.\mathrm{P} \cdot \mathrm{L}^{-1}\right)$ and $\mathrm{P}_{\mathrm{e}}$ is the effluent phosphorus concentration $\left(\mathrm{mg} \mathrm{P} \cdot \mathrm{L}^{-1}\right)$.

Since nutrient recovery of microalgae is highly influenced by the variability of light irradiance under outdoor conditions (Viruela et al., 2018), NRR and PRR were normalised by the total photosynthetic active radiation (tPAR) supplied to the PBRs to obtain the nitrogen recovery rate:light irradiance (NRR:I) (mg N. $\left.\mathrm{mol}^{-1}\right)($ Eq. 3) and phosphorus recovery rate:light irradiance ratio (PRR:I) (mg P. $\left.\mathrm{mol}^{-1}\right)($ Eq. 4).

$N R R: I=\frac{N R R \cdot V_{M P B R} \cdot 10^{9}}{t P A R \cdot S \cdot 24 \cdot 3600}$

$P R R: I=\frac{P R R \cdot V_{M P B R} \cdot 10^{9}}{t P A R \cdot S \cdot 24 \cdot 3600}$

where tPAR is the total PAR supplied to the PBR surface (i.e. the 24-hour average PAR plus the average PAR supplied by the LED lamps) ( $\mu \mathrm{mol}$ photons $\cdot \mathrm{m}^{-2} \cdot \mathrm{s}^{-1}$ ); and $\mathrm{S}$ is the illuminated PBR surface $\left(\mathrm{m}^{2}\right)$.

The biomass productivity $(\mathrm{BP})\left(\mathrm{mg} \mathrm{VSS} \cdot \mathrm{L}^{-1} \cdot \mathrm{d}^{-1}\right)$; i.e. the biomass produced and taken out of the PBRs was calculated by Eq. 5:

$B P=\frac{F_{w} \cdot V S S}{V_{M P B R}}$

[Eq. 5]

where $F_{w}\left(L \cdot d^{-1}\right)$ is the flow of the biomass wasted with the purge; and VSS (mg VSS $\mathrm{L}^{-}$

${ }^{1}$ ) is the volatile suspended solids concentration in the PBRs.

The photosynthetic efficiency (PE) (\%) was calculated according to Eq. 6:

$P E(\%)=\frac{B P_{m} \cdot H}{t I r \cdot S \cdot 24 \cdot 3600} \cdot 100$

[Eq. 6] 
where $\mathrm{BP}_{\mathrm{m}}$ is the microalgae productivity measured as $\mathrm{g} \mathrm{VSS} \cdot \mathrm{d}^{-1} ; \mathrm{H}$ is the enthalpy of dry biomass (i.e. $26.2 \mathrm{KJ} \cdot \mathrm{g} \mathrm{VSS}^{-1}$ for Chlorella vulgaris according to Norsker et al., 2011); and tr is the total PAR measured as energetic flux density $\left(\mathrm{KJ} \cdot \mathrm{m}^{-2} \cdot \mathrm{s}^{-1}\right)$.

The energy recovered from theoretical digestion of microalgae biomass (ER-BM) $\left(\mathrm{KWh} \cdot \mathrm{m}^{-3}{ }_{\text {inf }}\right.$ ) was obtained by Eq. 7 (modified from Viruela et al., 2018):

$E R-B M=\frac{B P_{C O D} \cdot Y_{C H 4} \cdot L H V \cdot \eta}{F} \quad[$ [Eq. 7]

where $\mathrm{BP}_{\mathrm{COD}}$ is the microalgae biomass productivity measured as $\mathrm{kg} \mathrm{COD} \cdot \mathrm{d}^{-1} ; \mathrm{Y}_{\mathrm{CH} 4}$ is the theoretical methane yield $\left(0.35 \mathrm{~m}^{3} \mathrm{CH}_{4} \cdot \mathrm{kg} \mathrm{COD}^{-1}\right.$ according to Ferrer et al. (2015)); LHV is the lower heating value for methane $\left(9.94 \mathrm{KWh} \cdot \mathrm{m}^{-3}\right)$; $\eta$ is the power generation efficiency of a methane-powered turbine electrical generator (set to $35 \%$ ) and $\mathrm{F}$ is the treatment flow rate $\left(\mathrm{m}^{3} \cdot \mathrm{d}^{-1}\right)$.

The nutrient contents of microalgae biomass (i.e. N:VSS $\left(\mathrm{mg} \mathrm{N}_{\mathrm{gVSS}}{ }^{-1}\right.$ ) and P:VSS $\left.\left(\mathrm{mg} \mathrm{P}_{\mathrm{gVSS}}{ }^{-1}\right)\right)$ were estimated considering that all the VSS corresponded to microalgae biomass:
$N: V S S=\frac{N_{P B R}}{V S S}$
[Eq. 8]
$P: V S S=\frac{P_{P B R}}{V S S}$
[Eq. 9]

where $\mathrm{N}_{\mathrm{PBR}}$ and $\mathrm{P}_{\mathrm{PBR}}$ are the suspended concentration of nitrogen $\left(\mathrm{mg} \mathrm{N} \cdot \mathrm{L}^{-1}\right)$ and phosphorus $\left(\mathrm{mg} \mathrm{P} \cdot \mathrm{L}^{-1}\right)$ of the microalgae culture, respectively.

The average irradiance inside the PBRs ( $\left.\mathrm{I}_{\mathrm{av}}\right)$ was obtained by applying the LambertBeer Law (Eq. 10) as reported by Romero-Villegas et al. (2017):

$$
I_{a v}=\frac{t P A R}{K_{a} \cdot C_{b} \cdot L p} \cdot\left(1-e^{-K_{a} \cdot C_{b} \cdot L p}\right) \quad[\text { Eq. 10] }
$$

Where tPAR is the sum of the solar and artificial PAR applied to the PBRs $\left(\mu \mathrm{mol} \cdot \mathrm{m}^{-2} \cdot \mathrm{s}^{-}\right.$ $\left.{ }^{1}\right), K_{a}$ is the culture extinction coefficient $\left(\mathrm{m}^{2} \cdot \mathrm{g}^{-1}\right.$, Eq. 11$), C_{b}$ is the culture biomass concentration $\left(\mathrm{g} \cdot \mathrm{m}^{-3}\right)$, and $\mathrm{Lp}$ is the light path $(\mathrm{m})$. 
The culture extinction coefficient $\left(\mathrm{K}_{\mathrm{a}}\right)$ is a light attenuation coefficient which considers the light scattering due to the microalgae biomass, microalgae pigments and other inert and organic compounds present in the culture (Eq. 11):

$K_{a}=\frac{O D_{400-700}}{C_{b} \cdot L p_{c}}$

where $\mathrm{OD}_{400-700}(-)$ is the average optical density of the culture measured in the range of $400-700 \mathrm{~nm}$; and $\mathrm{Lp}_{\mathrm{c}}(\mathrm{m})$ is the light path of the spectrophotometer's cuvette.

To assess membrane filtration, the $20^{\circ} \mathrm{C}$-standardised transmembrane flux $\left(\mathrm{J}_{20}\right)(\mathrm{LMH})$, the fouling rate $(\mathrm{FR})\left(\mathrm{mbar} \cdot \mathrm{min}^{-\mathbf{1}}\right)$, and the specific gas demand per volume of permeate produced $\left(\mathrm{SGD}_{\mathrm{p}}\right)\left(\mathrm{m}^{3}{ }_{\text {air }} \cdot \mathrm{m}^{-3}\right.$ permeate $)$ were calculated based on on-line monitored transmembrane flux $(\mathrm{J})(\mathrm{LMH})$ and transmembrane pressure $\left(\mathrm{TMP}_{\mathrm{Jn}}\right)$ data:

$J_{20}=J \cdot e^{-0.0239 \cdot(T-20)}$

$F R=\frac{n \cdot \sum_{1}^{n}\left(T M P_{i} \cdot t_{i}\right)+\sum_{1}^{n} T M P_{i} \cdot \sum_{1}^{n} t_{i}}{n \cdot \sum_{1}^{n} T M P_{i}^{2}-\left(\sum_{1}^{n} T M P_{i}\right)^{2}}$

$S G D_{P}=\frac{F_{a i r}}{J_{20} \cdot S_{m e m b}}$

where $\mathrm{T}$ is the culture temperature $\left({ }^{\circ} \mathrm{C}\right)$; $\mathrm{t}_{\mathrm{Jn}}$ is the time of the filtration stage $(\mathrm{min}) ; \mathrm{F}_{\text {air }}$ is the air flow for membrane scouring $\left(\mathrm{m}^{3} \cdot \mathrm{h}^{-1}\right)$ and $\mathrm{S}_{\mathrm{memb}}$ is the membrane surface area $\left(\mathrm{m}^{2}\right)$.

\subsection{Statistical analysis}

An analysis of variance (ANOVA) was carried out on SPSS 16.0, considering the following parameters: solar photosynthetic active radiation (PAR), temperature, VSS, OD680, TEC, DO concentration, $\mathrm{F}_{\mathrm{v}} / \mathrm{F}_{\mathrm{m}}$, nutrient (nitrogen and phosphorus) concentrations, chemical oxygen demand, NRR, PRR and biomass productivity. The correlation between the variables was considered significant at $\mathrm{p}$-value $<0.05$. 


\section{Results and Discussion}

\subsection{Effect of MPBR light path}

Under the same operating conditions, the 25-cm and 10-cm MPBR plants obtained significantly different results (see Table 3). A considerably higher biomass concentration was achieved in the 10-cm light path MPBR plant, which obtained higher biomass productivity than the $25-\mathrm{cm}$ MPBR plant (Table 3). This was because the photon flux density is exponentially reduced along the light path (Fernández-Sevilla et al., 2018), with a greater volume of the culture in darkness in the $25-\mathrm{cm}$ than in the 10 cm PBRs. Similarly, Huang et al. (2019) obtained higher biomass productivity at lower light path. However, their areal productivity (aBP) was lower in the narrowest PBR. According to Huang et al. (2019), wider light paths reach lower biomass concentrations. The shadow effect was thus expected to be less significant in the 25-cm MPBR plant. On the other hand, in the present study the narrowest PBRs achieved higher aBP, as well as a higher biomass productivity:light irradiance ratio (BP:I) and photosynthetic efficiency (see Table 3). This clearly demonstrated the more efficient use of light in the 10-cm MPBR plant than in the 25-cm MPBR plant. In fact, the extinction coefficient $\left(\mathrm{K}_{\mathrm{a}}\right)$, which represents light scattering in the culture due to the light path, culture biomass and the optical properties of microalgae cells (Romero-Villegas et al., 2017), was significantly lower in the 10-cm MPBR plant than in the 25-cm MPBR plant: 0.34 $\pm 0.02 \mathrm{~m}^{-2} \cdot \mathrm{g}^{-1}$ and $0.41 \pm 0.03 \mathrm{~m}^{2} \cdot \mathrm{g}^{-1}$, respectively. 
Table 3. Results obtained (mean \pm standard deviation) for 25-cm MPBR plant

(González-Camejo et al., 2019a); and 10-cm MPBR plant (present study).

\begin{tabular}{|c|c|c|c|}
\hline \multirow{2}{*}{ Parameter } & \multirow{2}{*}{ Unit } & \multicolumn{2}{|c|}{ Light path } \\
\hline & & $25 \mathrm{~cm}$ & $10 \mathrm{~cm}$ \\
\hline Solar PAR & $\mu \mathrm{mol} \cdot \mathrm{m}^{-2} \cdot \mathrm{s}^{-1}$ & $318 \pm 103$ & $271 \pm 142$ \\
\hline Temperature & ${ }^{\circ} \mathrm{C}$ & $23.5 \pm 1.1^{*}$ & $23.3 \pm 1.6^{*}$ \\
\hline VSS & $\mathrm{mg} \mathrm{VSS} \cdot \mathrm{L}^{-1}$ & $288 \pm 30$ & $920 \pm 110$ \\
\hline sCOD & $\mathrm{mg} \mathrm{COD} \cdot \mathrm{L}^{-1}$ & $76 \pm 39$ & $197 \pm 114$ \\
\hline BP & $\mathrm{mg} \mathrm{VSS} \cdot \mathrm{L}^{-1} \cdot \mathrm{d}^{-1}$ & $66 \pm 6$ & $194 \pm 24$ \\
\hline BP:I & $\mathrm{g} \mathrm{VSS} \cdot \mathrm{mol}^{-1}$ & $0.29 \pm 0.02$ & $0.42 \pm 0.05$ \\
\hline $\mathbf{a B P}$ & $\mathrm{g} \mathrm{VSS} \cdot \mathrm{m}^{-2} \cdot \mathrm{d}^{-1}$ & $15.7 \pm 1.4$ & $20.0 \pm 2.4$ \\
\hline NRR & $\mathrm{mg} \mathrm{N} \cdot \mathrm{L}^{-1} \cdot \mathrm{d}^{-1}$ & $9.1 \pm 1.5$ & $22.8 \pm 4.8$ \\
\hline PRR & $\operatorname{mg~P} \cdot \mathrm{L}^{-1} \cdot \mathrm{d}^{-1}$ & $1.07 \pm 0.54$ & $2.18 \pm 0.54$ \\
\hline NRR:I & $\mathrm{mg} \mathrm{N} \cdot \mathrm{mol}^{-1}$ & $45.6 \pm 1.9^{*}$ & $48.9 \pm 4.7^{*}$ \\
\hline PRR:I & $\mathrm{mg} \mathrm{P} \cdot \mathrm{mol}^{-1}$ & $5.34 \pm 1.42 *$ & $4.59 \pm 0.85^{*}$ \\
\hline aNRR & $\mathrm{g} \mathrm{N} \cdot \mathrm{m}^{-2} \cdot \mathrm{d}^{-1}$ & $2.18 \pm 0.36^{*}$ & $2.37 \pm 0.54 *$ \\
\hline aPRR & $\mathrm{g} \mathrm{P} \cdot \mathrm{m}^{-2} \cdot \mathrm{d}^{-1}$ & $0.29 \pm 0.13 *$ & $0.22 \pm 0.06^{*}$ \\
\hline NRE & $\%$ & $33.8 \pm 6.5$ & $73.5 \pm 14.6$ \\
\hline PRE & $\%$ & $36.0 \pm 9.1$ & $53.0 \pm 15.3$ \\
\hline PE & $\%$ & $3.02 \pm 0.36$ & $5.40 \pm 1.63$ \\
\hline $\mathbf{K}_{\mathbf{a}}$ & $\mathrm{m}^{2} \cdot \mathrm{g}^{-1}$ & $0.41 \pm 0.03$ & $0.34 \pm 0.02$ \\
\hline $\mathrm{N}:$ VSS & $\mathrm{mg} \mathrm{N} \cdot \mathrm{g} \mathrm{VSS}^{-1}$ & $139 \pm 23$ & $111 \pm 27$ \\
\hline P:VSS & $\mathrm{mg} \mathrm{P} \cdot \mathrm{g} \mathrm{VSS}^{-1}$ & $18 \pm 8$ & $11 \pm 3$ \\
\hline FR & $\mathrm{mbar} \cdot \mathrm{min}^{-1}$ & $\sim 5$ & $22-30$ \\
\hline
\end{tabular}

*Showed non-statistically significant differences ( $p$-value > 0.05).

aBP: areal biomass productivity; aNRR: areal nitrogen recovery rate; aPRR: areal phosphorus recovery rate; BP: biomass productivity; BP:I: biomass productivity: light irradiance ratio; FR: fouling rate; $K_{a}$ : extinction coefficient; NRE: nitrogen recovery efficiency; NRR: nitrogen recovery rate; NRR:I: nitrogen recovery rate: light irradiance ratio; $N$ :VSS: nitrogen content in the biomass; PAR: photosynthetically active radiation; PE: photosynthetic efficiency; PRE: phosphorus recovery efficiency; PRR: phosphorus recovery rate; PRR:I: phosphorus recovery rate: light irradiance ratio; P:VSS: phosphorus content in the biomass; sCOD: soluble chemical oxygen demand; VSS: volatile suspended solids. 
Regarding nutrients, the $10-\mathrm{cm}$ PBRs showed significantly higher nutrient recovery rates; i.e. NRR was $150 \%$ and PRR was $103 \%$ higher than the $25-\mathrm{cm}$ PBRs, so that the nutrient recovery efficiencies obtained in the 10-cm PBRs were considerably higher than in the widest PBRs (see Table 3). On the other hand, areal nutrient recovery rates and nutrient recovery rates:light irradiance ratios did not present any statistically significant differences (Table 3). This can be explained by the capability of microalgae to assimilate nutrients in darkness until they reach their maximum intracellular nutrient content (Ruiz et al., 2014). Under dark conditions, microalgae are not able to grow photoautrotophically, but green microalgae Chlorella is also able to grow heterotrophically in darkness. In this respect, heterotrophic growth of microalgae can be either faster or slower than photoautrophic depending on cultivating conditions and the organic carbon source (Ferreira et al., 2019). In the case of this study, organic carbon was not expected to boost heterotrophic metabolism since it was not easily degradable. In fact, BOD in the influent (AnMBR effluent) only accounted for $27 \pm 2 \mathrm{mg} C O D \cdot \mathrm{L}^{-1}$. Moreover, the organic matter released by microalgae activity and cell debris was mainly composed by long-chain molecules such as proteins and polysaccharides, which usually present lower microalgae growth than other pure carbohydrates (Ferreira et al., 2019). Photoautotrophic metabolism was thus expected to be favoured. In fact, in the $25-\mathrm{cm}$ PBRs, which had higher volumes in darkness, microalgae growth was lower, therefore presenting higher nutrient content per unit of biomass, as shown in Table 3.

Overall, reducing the MPBR light path from 25 to $10 \mathrm{~cm}$ provided better microalgae performance in AnMBR effluent treatment. This suggests that the light path should be optimised to obtain maximum MPBR performance. However, it also has to be remembered that too narrow light paths can significantly increase biofouling, which sharply reduces the light available to the culture. 
Apart from the better results obtained from the 10-cm PBRs (Table 3), the higher biomass concentration in these PBRs has been reported to strengthen microalgae culture and protect it against grazers (Day et al., 2017; Fernández et al., 2016), making it more consistent. However, increasing biomass concentration in the 10-cm MPBR plant involved a rise in sCOD concentration from $76 \pm 39 \mathrm{mg} \mathrm{COD} \cdot \mathrm{L}^{-1}$ in the $25-\mathrm{cm} \mathrm{MPBR}$ plant to $197 \pm 114 \mathrm{mg} C O D \cdot \mathrm{L}^{-1}$ in the $10-\mathrm{cm}$ MPBR plant. sCOD concentration was used as an indicator of the culture's AOM concentration (Figure A.2), which has been reported to negatively affect the filtration process (Liu et al., 2017; Henderson et al., 2008). The fouling rate (FR) obtained in the $10-\mathrm{cm}$ MPBR plant was thus significantly higher than that in the $25-\mathrm{cm}$ MPBR plant under similar $\mathrm{J}_{20}$ of around $26 \mathrm{LMH}$ (Table 3). It must be highlighted that as Chlorella was the dominant species in both MPBR plants, the differences related to the culture characteristics were thus not considered. It should also be considered that the BP:I value of $0.42 \pm 0.05 \mathrm{~g} \mathrm{VSS} \cdot \mathrm{mol}^{-1}$ obtained in the 10-cm PBRs was significantly lower than that reported by Jebali et al. (2018), i.e. $1.0 \mathrm{~g} \mathrm{VSS} \cdot \mathrm{mol}^{-1}$. In addition, the photosynthetic efficiency of $5.40 \pm 1.63 \%$ attained in the narrowest PBRs, in spite of being higher than the common values in large scale plants, which are usually in the range of $1.5-2 \%$ (Nwoba et al., 2019), is still far from the theoretical optimum of microalgae: around 10\% (Romero-Villegas et al., 2017). The high biomass concentration of $920 \pm 110 \mathrm{mg} \mathrm{VSS} \cdot \mathrm{L}^{-1}$, was thought to be mainly responsible for this light limitation, since the microalgae close to the surface absorb most of the light photons, scattering the deeper PBR zones (Barceló-Villalobos et al., 2019; Nwoba et al., 2019). In this respect, SRT has been reported as a key parameter in adjusting biomass concentration and improving light availability (Huang et al., 2019; Luo et al., 2018). As this optimum SRT varies with the type of reactor, in spite of having defined the optimal operating conditions for the 25-cm PBRs in a previous study 
(González-Camejo et al., 2019a), the optimum range of operating conditions must be defined for the more efficient 10-cm MPBR plant, with the goal of obtaining robust culture that can also take full advantage of the solar light received.

\subsection{Optimisation of operating conditions}

During the entire operating period of the $10-\mathrm{cm}$ MPBR plant, the culture was dominated by the indigenous Chlorella genus (> 99\% of TEC). Chlorella has been reported to have a strong resistance to protozoa, especially when they are adapted to the region in which they are cultivated (Thomas et al., 2019). Scenedesmus was also present in the original inoculum (see Section 2.1). However, their presence during the operation of the MPBR plant was negligible, probably because the operating conditions favoured the growth of Chlorella, which are strong competitors for light and nutrients (Galès et al., 2019).

During Period $1(\mathrm{SRT}=4.5 \mathrm{~d} ; \mathrm{HRT}=1.5 \mathrm{~d})$; Period $2(\mathrm{SRT}=3 \mathrm{~d} ; \mathrm{HRT}=1.5 \mathrm{~d})$; and Period $3($ SRT $=3 \mathrm{~d}$; HRT $=1.25 \mathrm{~d})$, the MPBR plant effluent was able to meet the legal requirements of Directive 91/271/CEE for a 10,000-100,000-p.e WWTP discharging to sensitive areas, i.e. effluent nutrient concentrations under $15 \mathrm{mg} \mathrm{N} \cdot \mathrm{L}^{-1}$ and $2 \mathrm{mg} \mathrm{P} \cdot \mathrm{L}^{-1}$ (except for several days in Period 2, when nitrogen effluent concentration reached $20 \mathrm{mg} \mathrm{N} \cdot \mathrm{L}^{-1}$ due to the sudden increase in nitrogen load (see Figure 2)). Nitrogen recovery efficiency (NRE) and phosphorus recovery efficiency (PRE) attained the high values of $80-85 \%$ and $90-99 \%$, respectively, which also accomplished the legal requirements of Directive 91/271/CEE, i.e. $70-80 \%$ and $70 \%$ for nitrogen and phosphorus, respectively. 


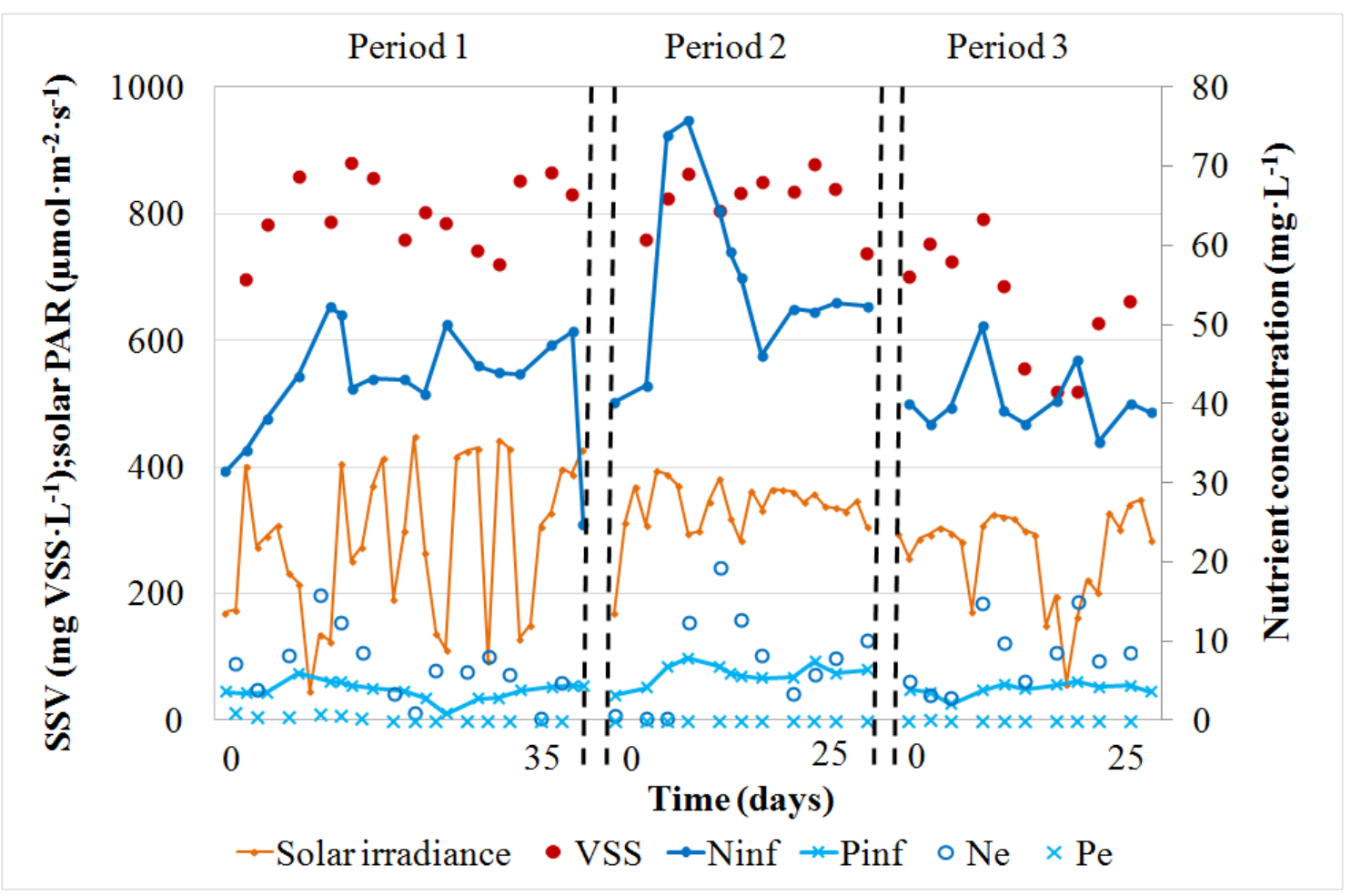

Figure 2: Pseudo-steady state conditions. Evolution of the concentration of the volatile suspended solids (VSS) (mgVSS $\left.\mathrm{L}^{-1}\right)$, daily average solar photosynthetic active radiation $(\mathrm{PAR})\left(\mu \mathrm{mol} \cdot \mathrm{m}^{-2} \cdot \mathrm{s}^{-1}\right)$, nitrogen concentration of the influent (Ninf) and effluent $(\mathrm{Ne})(\mathrm{mg}$ $\left.N \cdot L^{-1}\right)$ and phosphorus concentration of the influent (Pinf) and effluent (Pe) (mg P.L $\left.L^{-1}\right)$

On the other hand, when the 10-cm MPBR plant was operated at a HRT of $1 \mathrm{~d}$ and SRT of $2 \mathrm{~d}$, heterotrophic and nitrifying bacteria activity was favoured, which negatively affected microalgae performance. The legal requirements were thus not complied with these operating conditions (Appendix B). It can thus be concluded that the MPBR plant was able to properly treat AnMBR effluent at SRT and HRT in the range of 3-4.5 $\mathrm{d}$ and $1.25-1.5 \mathrm{~d}$, respectively.

It is surprising that the longest HRT that accomplished legal requirements (i.e. $1.5 \mathrm{~d}$ ) in the 10-cm MPBR plant was significantly lower than that which managed to satisfy the legal limits in the 25-cm MPBR plant; i.e. 3.5 d (González-Camejo et al., 2019a). This means around $27 \%$ reduction in the capital expenditures (CAPEX) of the 10-cm MPBR 
plant in comparison with the 25-cm MPBR plant (Appendix C). It should also be noted that this reduction in CAPEX was obtained without using any nitrification inhibitor, unlike the previous study (González-Camejo et al., 2019a). However, significant nitrification was not detected during the operation of the $10-\mathrm{cm}$ MPBR plant since $\mathrm{NO}_{\mathrm{x}}$ concentrations, which served as an indicator of nitrifying bacteria activity (see Section 3.3), always remained at low values $\left(<7.5 \mathrm{mg} \mathrm{N} \cdot \mathrm{L}^{-1}\right)$.

The $\mathrm{I}_{\mathrm{av}}$ values obtained for Periods 1,2 and 3 (i.e., $21 \pm 5 \mu \mathrm{mol} \cdot \mathrm{m}^{-2} \cdot \mathrm{s}^{-1}, 21 \pm 2 \mu \mathrm{mol} \cdot \mathrm{m}^{-}$ ${ }^{2} \cdot \mathrm{s}^{-1}$ and $24 \pm 2 \mu \mathrm{mol} \cdot \mathrm{m}^{-2} \cdot \mathrm{s}^{-1}$, respectively) were significantly lower than the ones obtained by Jebali et al. (2018) for green microalgae Scenedesmus sp. (125-263 $\left.\mu \mathrm{mol} \cdot \mathrm{m}^{-2} \cdot \mathrm{s}^{-1}\right)$. According to Barceló-Villegas et al. (2019), the minimum light irradiance for photosynthesis is around $40 \mu \mathrm{mol} \cdot \mathrm{m}^{-2} \cdot \mathrm{s}^{-1}$, so that the system was likely to be photolimited. The high values of the extinction coefficient obtained in the $10-\mathrm{cm}$ MPR plant (in spite of being lower than in the $25-\mathrm{cm}$ MPBR plant) were considered the main reason of the low light availability (Sepúlveda et al., 2015). For Periods 1, 2 and 3, the plant's $K_{a}$ value accounted for $0.35 \pm 0.01 \mathrm{~m}^{2} \cdot \mathrm{g}^{-1}, 0.37 \pm 0.01 \mathrm{~m}^{-2} \cdot \mathrm{g}^{-1}$ and $0.34 \pm$ $0.03 \mathrm{~m}^{2} \cdot \mathrm{g}^{-1}$, respectively; while Jebali et al. (2018) achieved extinction coefficients in the range of $0.06-0.13 \mathrm{~m}^{2} \cdot \mathrm{g}^{-1}$. The shadow effect in the MPBR plant was thus highly relevant.

Period 2 (SRT of $3 \mathrm{~d}$ and HRT of $1.5 \mathrm{~d}$ ) presented the highest NRR and PRR values of all three periods analysed: $29.7 \pm 4.6 \mathrm{mg} \mathrm{N} \cdot \mathrm{L}^{-1} \cdot \mathrm{d}^{-1}$ and $3.8 \pm 0.6 \mathrm{mg} \mathrm{P} \cdot \mathrm{L}^{-1} \cdot \mathrm{d}^{-1}$, respectively. These values are notably higher than most of the results reported for similar microalgae-based pilot plants so far (Table 4). In fact, only the authors who treated centrate (Romero-Villegas et al., 2017; 2018) obtained higher values than those obtained in the present study, due to the fact that centrate contains higher nutrient concentrations than wastewater from both secondary and AnMBR effluents (Gao et al., 
2019). These nutrient recovery rates obtained in Period 2 made microalgae contain up to $101.0 \pm 3.3 \mathrm{mg} \mathrm{N} \cdot \mathrm{g} \mathrm{VSS}^{-1}$ of nitrogen and $11.3 \pm 2.0 \mathrm{mg} \mathrm{P} \cdot \mathrm{g} \mathrm{VSS}^{-1}$ of phosphorus in their biomass, which highlights their features as a fertiliser/bio-stimulant (Seco et al., 2018; Xu et al., 2019). Period 2 also attained the highest biomass productivity: $258 \pm 20$ $\mathrm{mg} \mathrm{VSS} \cdot \mathrm{L}^{-1} \cdot \mathrm{d}^{-1}$. If this microalgae biomass would be anaerobically digested, the biogas produced could serve as a source of energy which would theoretically account for 0.940

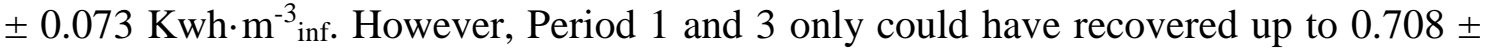
$0.187 \mathrm{Kwh} \cdot \mathrm{m}^{-3}{ }_{\text {inf }}$ and $0.567 \pm 0.112 \mathrm{Kwh} \cdot \mathrm{m}^{-3}{ }_{\text {inf }}$, respectively, due to their lower biomass production.

Table 4. Nutrient removal rates of microalgae-based wastewater treatment studies under outdoor conditions.

\begin{tabular}{|c|c|c|c|c|c|c|}
\hline $\begin{array}{l}\text { Type of } \\
\text { reactor }\end{array}$ & $\begin{array}{c}\text { Type of } \\
\text { wastewater }\end{array}$ & $\begin{array}{l}\text { HRT } \\
\text { (d) }\end{array}$ & $\begin{array}{l}\text { SRT } \\
\text { (d) }\end{array}$ & $\begin{array}{c}\mathrm{NRR} \\
\left(\mathrm{mg} \mathrm{N} \cdot \mathrm{L}^{-1} \cdot \mathrm{d}^{-1}\right)\end{array}$ & $\begin{array}{c}\text { PRR } \\
\left(\mathrm{mg} \mathrm{P} \cdot \mathrm{L}^{-1} \cdot \mathrm{d}^{-1}\right)\end{array}$ & Reference \\
\hline $\begin{array}{l}\text { Flat-panel } \\
\text { MPBR }\end{array}$ & $\begin{array}{l}\text { AnMBR } \\
\text { effluent }\end{array}$ & 1.5 & 3 & 29.7 & 3.8 & This study \\
\hline HRAP & $\begin{array}{l}\text { Secondary } \\
\text { effluent }\end{array}$ & 10 & 10 & 3.99 & 0.36 & $\begin{array}{l}\text { Arbib et al. } \\
\text { (2017) }\end{array}$ \\
\hline $\begin{array}{c}\text { Flat-panel } \\
\text { MPBR }\end{array}$ & $\begin{array}{l}\text { AnMBR } \\
\text { effluent }\end{array}$ & 3.5 & 4.5 & 11.1 & 1.42 & $\begin{array}{c}\text { González- } \\
\text { Camejo et al. } \\
(2019 a)\end{array}$ \\
\hline HRAP & $\begin{array}{l}\text { Raw urban } \\
\text { wastewater }\end{array}$ & 10 & 10 & 1.9 & 0.32 & $\begin{array}{l}\text { Iasimone et al. } \\
\text { (2017) }\end{array}$ \\
\hline Tubular PBR & $\begin{array}{l}\text { Seawater + } \\
\text { centrate }\end{array}$ & 3.3 & 3.3 & 36.9 & 5.38 & $\begin{array}{c}\text { Romero-Villegas } \\
\text { et al. (2017) }\end{array}$ \\
\hline Raceway & $\begin{array}{l}\text { Seawater }+ \\
\text { centrate }\end{array}$ & 3.3 & 3.3 & 28.7 & 3.99 & $\begin{array}{l}\text { Romero-Villegas } \\
\text { et al. (2018) }\end{array}$ \\
\hline $\begin{array}{c}\text { Flat-panel } \\
\text { PBR }\end{array}$ & $\begin{array}{l}\text { AnMBR } \\
\text { effluent }\end{array}$ & $3-4$ & 4.5 & 8.1 & 1.0 & $\begin{array}{l}\text { Viruela et al. } \\
\text { (2018) }\end{array}$ \\
\hline $\begin{array}{c}\text { Flat-panel } \\
\text { PBR }\end{array}$ & $\begin{array}{l}\text { AnMBR } \\
\text { effluent }\end{array}$ & $3-4$ & 9 & 3.3 & 0.4 & $\begin{array}{c}\text { Viruela et al. } \\
\text { (2018) }\end{array}$ \\
\hline
\end{tabular}

AnMBR: anaerobic membrane bioreactor; HRAP: high rate algal pond; HRT: hydraulic retention time; MPBR: membrane photobioreactor; NRR: nitrogen recovery rate; PBR: photobioreactor; PRR: phosphorus recovery rate; SRT: solids retention time. 
As Periods 1, 2 and 3 received different levels of solar irradiance (Table 2), these periods should be properly compared by normalising the parameters related to MPBR performance (NRR, PRR and BP) by light irradiance, i.e., NRR:I, PRR:I and photosynthetic efficiency, respectively (González-Camejo et al., 2019a). It must be noted that the effect of the culture temperature in MPBR performance during the different operating periods was not considered since deleterious temperatures over 32$35^{\circ} \mathrm{C}$ (González-Camejo et al., 2019b) were avoided by cooling the system (see Section 2.2). Under these controlled conditions, temperature did not appear to be a relevant factor regarding microalgae performance in comparison to SRT and HRT (GonzálezCamejo et al., 2020). Similarly, the effect of nutrient concentration in the culture (which is analogous to the nutrient concentration in the effluent as the system is considered to be well mixed) was not considered either since nitrogen and phosphorus concentrations were similar during Periods 1, 2 and 3 (Figure 2).

NRR:I, PRR:I and photosynthetic efficiency showed similar values for Periods 2 and 3 (p-value $>0.05$, see Figure 3). Hence, similar results were obtained by operating the system within an HRT range of 1.25-1.5 d. On the other hand, in Period 1 (SRT $4.5 \mathrm{~d}$ and HRT $1.5 \mathrm{~d}$ ), the legal requirements were accomplished (Figure 2), although NRR:I, PRR:I and photosynthetic efficiency were significantly lower than in Periods 2 and 3 (Figure 3), so that operating at a SRT of $4.5 \mathrm{~d}$ was not considered appropriate to optimise this system. Under these operating conditions, microalgae were probably not at their exponential growth rate, since 4.5-d was longer than the theoretical optimum SRT of 2.3-3 d (see Appendix A). As a consequence, viability of microalgae biomass under 4.5-d SRT was probably reduced (Luo et al., 2018). These results highlight the 
importance of operating this MPBR plant at SRT/HRT in the range of around 3/1.25-1.5 d to achieve best MPBR performance.

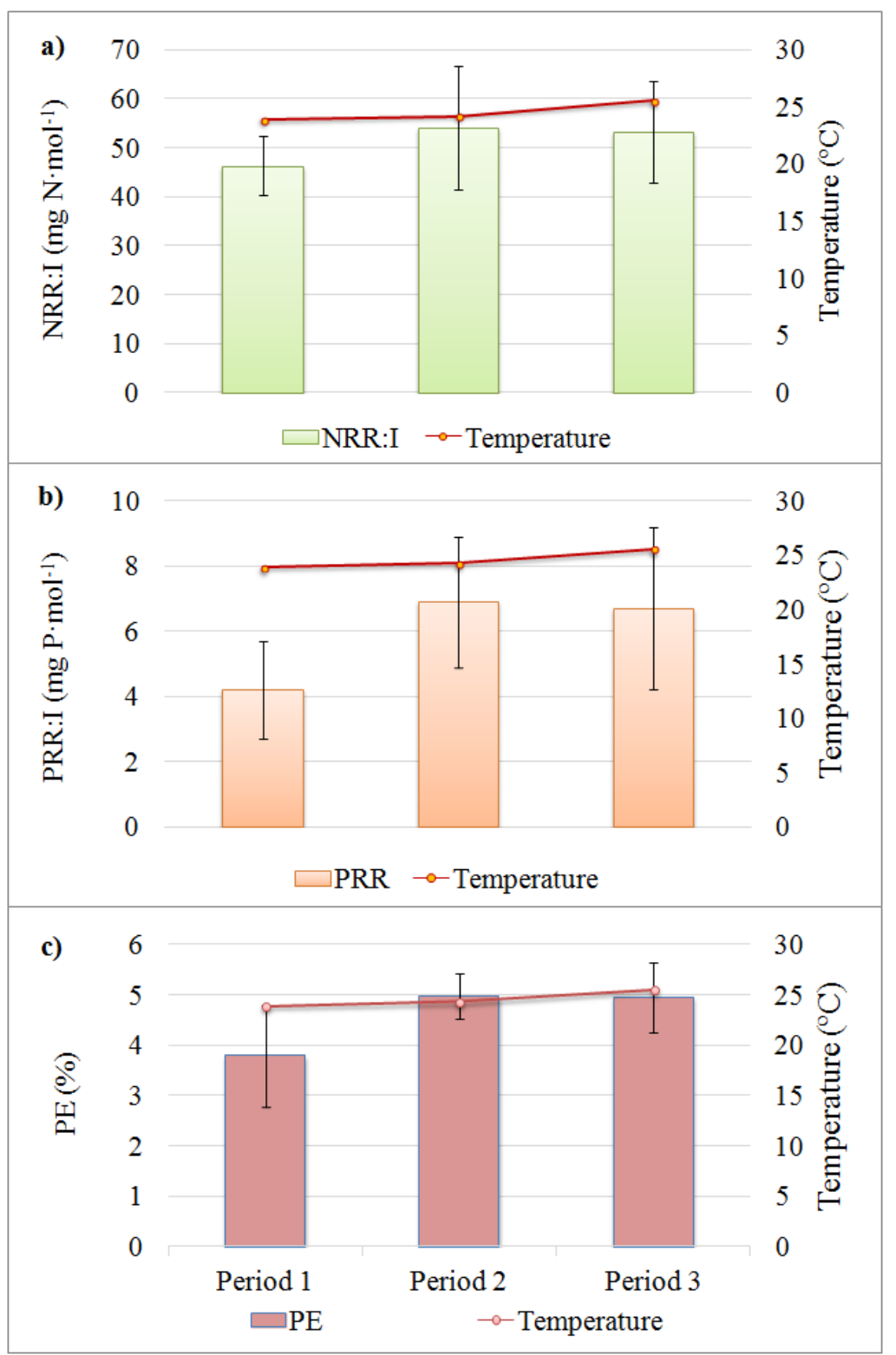

Figure 3. Average values of the control parameters during pseudo-steady state conditions of Period $1(S R T=4.5 d, H R T=1.5 d) ; \operatorname{Period} 2(S R T=3 d, H R T=1.5 d)$ and Period $3(S R T=3 d, H R T=1.25 d)$. a) Nitrogen recovery rate:light irradiance (NRR) ratio $\left(\mathrm{mg} \mathrm{N}^{\mathrm{m}} \mathrm{mol}^{-1}\right)$; b) phosphorus recovery rate:light irradiance (PRR:I) ratio ( $m g$ P.mol $\left.{ }^{-1}\right)$; and c) photosynthetic efficiency (PE) (\%). 
With respect to the filtration process, the MPBR plant started operations with a $\mathbf{J}_{20}$ of around $26 \mathrm{LMH}$ and $\mathrm{SGD}_{\mathrm{p}}$ of $16-20 \mathrm{Nm}^{3}{ }_{\text {air }} \cdot \mathrm{m}^{-3}$ permeate during Period 1 (Figure 4). However, the maximum TMP of 0.5 bar was rapidly reached after 14 days (data not shown). At this point the membrane needed chemical cleaning, which reduced FR to 10 mbar. $\min ^{-1} .11$ days of operation at similar $\mathrm{J}_{20}$ and $\mathrm{SGD}_{\mathrm{p}}$ after this cleaning stage, FR rapidly increased, reaching maximum TMP on day 25 . The membranes were therefore chemically cleaned again on day 26 , which reduced FR to $13 \mathrm{mbar} \cdot \mathrm{min}^{-1}$ (Figure 4). Hence, working at a $\mathbf{J}_{20}$ of $26 \mathrm{LMH}$ was confirmed not to be appropriate for this MPBR system, as frequent chemical cleaning was required and this increased the operating costs (Seco et al., 2018) and reduced membrane life. For this reason, $\mathbf{J}_{20}$ was reduced significantly from 26 to $15 \mathrm{LMH}$ after day 26, so that FR remained at low values (7-13 mbar $\cdot \min ^{-1}$ ) until the end of Period 1 . At the same time, $\mathrm{SGD}_{\mathrm{p}}$ was kept approximately constant $\left(16-20 \mathrm{Nm}_{\text {air }}^{3} \mathrm{~m}^{-3}\right.$ permeate), which meant that $\mathrm{SGD}_{\mathrm{m}}$ fell from 0.4 to $0.3 \mathrm{Nm}^{3} \cdot \mathrm{m}^{-}$ ${ }^{2} \cdot \mathrm{h}^{-1}$ on average. This entailed reducing the OPEX associated with air pumping and chemical cleanings of the membrane (Seco et al., 2018).

The membrane performance in Period 2 showed no significant differences with Period 1 (from day 26 until day 35) as regards the fouling rate since it remained at 5-15 mbar $\min ^{-1}$ (Figure 4); probably because the average VSS and sCOD concentrations were similar (Lee et al., 2018); i.e. $801 \pm 60 \mathrm{mg} \mathrm{VSS} \cdot \mathrm{L}^{-1}$ and $228 \pm 44 \mathrm{mg} \mathrm{COD} \cdot \mathrm{L}^{-1}$ for Period 1; and $823 \pm 44 \mathrm{mg} \mathrm{VSS} \cdot \mathrm{L}^{-1}$ and $239 \pm 43 \mathrm{mg} \mathrm{COD} \cdot \mathrm{L}^{-1}$ for Period 2 (p-value > 0.05). On the other hand, Period 3 started with a similar FR to Period 2 (around 5-15 $\operatorname{mbar} \cdot \min ^{-1}$ ). However, due to reduced solar irradiance (Figure 2), microalgae activity fell, which entailed VSS concentration dropping from $731 \pm 42 \mathrm{mg} \mathrm{VSS} \cdot \mathrm{L}^{-1}$ to $531 \pm 21$ $\mathrm{mg} \mathrm{VSS} \cdot \mathrm{L}^{-1}$ and sCOD concentration decreased from $248 \pm 2 \mathrm{mg} \mathrm{COD} \cdot \mathrm{L}^{-1}$ to $75 \pm 7 \mathrm{mg}$ $\mathrm{COD} \cdot \mathrm{L}^{-1}$. The lower VSS and SCOD concentrations were thus considered to be related 
to the FR falling from 10 to $3 \mathrm{mbar} \cdot \mathrm{min}^{-1}$ during days $15-20$ of Period 3 (Figure 4). In this respect, Luo et al. (2019) reported that differences in fouling rate are mainly due to microalgae biomass concentration and algal organic matter since they tend to increase cake layer formation and reduce the turbulence on membrane surface.

Overall, non-significant differences in the membrane performance were observed under the operating SRTs and HRTs. The filtration process could be operated with a low fouling propensity when $\mathrm{J}_{20}$ of $15 \mathrm{LMH}$ and $\mathrm{SGD}_{\mathrm{p}}$ between 16 and $20 \mathrm{Nm}^{3}$ air $\mathrm{m}^{-3}$ permeate were applied, which highlights the potential of membrane filtration for microalgae cultivation in MPBRs.

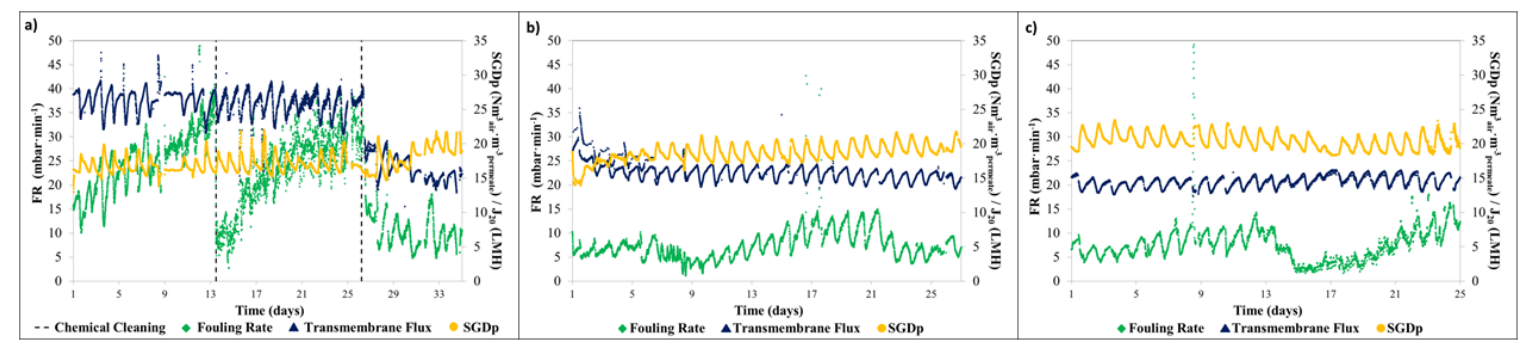

Figure 4. Membrane filtration performance at the 10-cm MPBR plant during pseudosteady state conditions: a) Period $1(S R T=4.5 d, H R T=1.5 d) ; b)$ Period $2(S R T=3$ $d, H R T=1.5 d) ; c)$ Period $3(S R T=3 d, H R T=1.25 d)$.

\subsection{Key performance indicators}

An ANOVA analysis was carried out on data collected during the entire study period (around 8 months, excluding cleaning and start-up stages), considering only the parameters mentioned in Section 2.5. The results are shown in Table 5. 
Table 5. Results of the ANOVA analysis for the long-term MPBR plant operation (only shows the paired parameters with a significant correlation: $p$-value $<0.05$; in bold, $p$ -

value $<0.01$ ).

\begin{tabular}{|c|c|c|c|c|c|c|c|c|c|c|c|c|}
\hline & & PAR & $\mathbf{T}$ & DO & VSS & $\mathrm{NO}_{\mathrm{x}}$ & $\mathbf{F}_{\mathrm{v}} / \mathbf{F}_{\mathrm{m}}$ & COD & sCOD & NRR & PRR & BP \\
\hline \multirow[t]{2}{*}{ PAR } & $\mathrm{R}^{2}$ & 1.000 & N/A & N/A & N/A & N/A & N/A & N/A & N/A & 0.456 & 0.276 & N/A \\
\hline & $\mathrm{N}$ & 122 & & & & & & & & 118 & 118 & \\
\hline \multirow[t]{2}{*}{$\mathbf{T}$} & $\mathrm{R}^{2}$ & N/A & 1.000 & N/A & N/A & N/A & N/A & N/A & N/A & 0.220 & 0.226 & N/A \\
\hline & $\mathrm{N}$ & & 122 & & & & & & & 118 & 118 & \\
\hline \multirow[t]{2}{*}{ DO } & $\mathrm{R}^{2}$ & N/A & N/A & 1.000 & 0.310 & N/A & N/A & N/A & N/A & 0.246 & N/A & 0.337 \\
\hline & $\mathrm{N}$ & & & 122 & 114 & & & & & 115 & & 109 \\
\hline \multirow[t]{2}{*}{ VSS } & $\mathrm{R}^{2}$ & N/A & N/A & 0.310 & 1.000 & -0.500 & -0.380 & 0.905 & 0.581 & 0.215 & N/A & 0.417 \\
\hline & $\mathrm{N}$ & & & 114 & 114 & 114 & 107 & 24 & 30 & 113 & & 111 \\
\hline \multirow[t]{2}{*}{$\mathbf{N O}_{\mathbf{x}}$} & $\mathrm{R}^{2}$ & N/A & N/A & N/A & -0.500 & 1.000 & N/A & -0.490 & -0.485 & -0.239 & N/A & -0.232 \\
\hline & $\mathrm{N}$ & & & & 114 & 122 & & 26 & 30 & 118 & & 112 \\
\hline \multirow[t]{2}{*}{$\mathbf{F}_{\mathrm{v}} / \mathbf{F}_{\mathrm{m}}$} & $\mathrm{R}^{2}$ & N/A & N/A & N/A & -0.380 & N/A & 1.000 & N/A & N/A & N/A & N/A & -0.214 \\
\hline & $\mathrm{N}$ & & & & 107 & & 114 & & & & & 105 \\
\hline \multirow[t]{2}{*}{ COD } & $\mathrm{R}^{2}$ & N/A & N/A & N/A & 0.905 & -0.490 & N/A & 1.000 & 0.591 & N/A & -0.462 & -0.232 \\
\hline & $\mathrm{N}$ & & & & 24 & 26 & & 26 & 24 & & 26 & 112 \\
\hline \multirow[t]{2}{*}{ sCOD } & $\mathrm{R}^{2}$ & N/A & N/A & N/A & 0.581 & -0.485 & N/A & 0.591 & 1.000 & N/A & N/A & N/A \\
\hline & $\mathrm{N}$ & & & & 30 & 30 & & 24 & 30 & & & \\
\hline \multirow[t]{2}{*}{ NRR } & $\mathrm{R}^{2}$ & 0.456 & 0.220 & 0.246 & 0.215 & -0.239 & N/A & N/A & N/A & 1.000 & 0.548 & 0.495 \\
\hline & $\mathrm{N}$ & 118 & 118 & 115 & 113 & 118 & & & & 118 & 118 & 109 \\
\hline \multirow[t]{2}{*}{ PRR } & $\overline{\mathrm{R}^{2}}$ & 0.276 & 0.226 & N/A & N/A & N/A & N/A & -0.462 & N/A & 0.548 & 1.000 & 0.364 \\
\hline & $\mathrm{N}$ & 118 & 118 & & & & & 26 & & 118 & 118 & 109 \\
\hline \multirow[t]{2}{*}{$\mathbf{B P}$} & $\mathrm{R}^{2}$ & N/A & N/A & 0.337 & 0.417 & -0.232 & -0.214 & N/A & N/A & 0.495 & 0.364 & 1.000 \\
\hline & $\mathrm{N}$ & & & 109 & 111 & 112 & 105 & & & 109 & 109 & 112 \\
\hline
\end{tabular}

PAR: photosynthetically active par; T: temperature; DO: dissolved oxygen; OD680: optical density at $680 \mathrm{~nm} ;$ NOx: nitrite + nitrate concentration in the effluent; $F_{\sqrt{ }} / F_{m}$ : maximum quantum efficiency; COD: chemical oxygen demand; sCOD: soluble chemical oxygen demand; NRR: nitrogen recovery rate; PRR: phosphorus recovery rate; BP: biomass productivity; $R^{2}$ : correlation coefficient; $N$ : number of samples.

A high correlation was found between VSS concentration and OD680 ( $\mathrm{p}$-value $<0.01$; $\left.\mathrm{R}^{2}=0.908 ; \mathrm{n}=109\right)$. VSS concentration was also highly correlated with TEC ( $\mathrm{p}$-value $<0.01 ; \mathrm{R}^{2}=0.753 ; \mathrm{n}=32$ ), which suggests that the culture biomass was mainly composed of eukaryotic microalgae, even when there was noticeable growth of heterotrophic and nitrifying bacteria (Periods $3 \mathrm{~b}$ and 4 in Appendix B). In fact, the 
relation between OD680 and TEC was also significant $\left(\mathrm{p}\right.$-value $<0.01 ; \mathrm{R}^{2}=0.799 ; \mathrm{n}=$ 32). Similar behaviour was observed in previous study which considered not only a microalgae culture dominated by Chlorella but also a culture in which Scenedesmus was the most abundant microalgae genus (González-Camejo et al., 2020). OD680 therefore seems to be a good indicator of microalgae cell concentration in this system.

The results also showed a correlation between ambient conditions (i.e. light and temperature) and nutrient recovery rates (NRR and PRR), as previously reported by Viruela et al. (2018). However, the data was disperse (i.e. low $\mathrm{R}^{2}$ values), probably due to the high variability of these ambient conditions throughout the day (Galès et al., 2019) and seasonal variations. Sunlight and temperatures are thus key parameters and should be continuously monitored to correctly assess MPBR performance.

It should be noted that the correlation of PRR with ambient conditions was lower than that of NRR (lower $\mathrm{R}^{2}$; see Table 5), probably because the MPBR plant was operated in P-deplete conditions for many days, as can be seen in Figure 2. However, P-depletion was not considered to limit microalgae growth since they have been reported to successfully grow under P-starvation (Solovchenko et al., 2019) using intracellular phosphorus. In fact, a significant correlation was found between PRR and biomass productivity (Table 5).

DO concentration was related to NRR and biomass productivity (Table 5) in spite of being influenced not only by microalgae photosynthetic activity (Fernández-Sevilla et al., 2018) but also by other factors such as temperature and bacterial activity (Rossi et al., 2018), and thus could be used as an MPBR performance indicator during the continuous MPBR operations.

$\mathrm{NO}_{\mathrm{x}}$ concentration can be used as an indirect measure of nitrifying bacteria activity (Galès et al., 2019; González-Camejo et al., 2020). It was inversely correlated to VSS, 
COD, NRR and biomass productivity (Table 5), which confirmed that the proliferation of nitrifying bacteria worsened MPBR performance due to microalgae-AOB competition for ammonium uptake (González-Camejo et al., 2020). In this respect, it has to be considered that lab-scale assays using similar microalgae culture and substrate showed that ammonium uptake rate of microalgae can be up to 15 times higher than those of nitrite and nitrate (González-Camejo et al., 2019b). Moreover, lab-scale respirometric tests also showed that microalgae activity is significantly limited when ammonium concentration in the culture is lower than $10 \mathrm{mg} \mathrm{N} \cdot \mathrm{L}^{-1}$ (González-Camejo et al., 2019c).

sCOD in the influent (which was analogous to total COD as it was preceded by a filtration process (see Section 2.1.)) only accounted for $71 \pm 35 \mathrm{mg} \mathrm{COD} \cdot \mathrm{L}^{-1}$, while sCOD inside the PBRs rose to $153 \pm 73 \mathrm{mg} \mathrm{COD} \cdot \mathrm{L}^{-1}$, probably due to microalgae activity as explained in Appendix A. In fact, a significant correlation was found between VSS concentration (which was in turn related to microalgae cells as aforementioned) and sCOD (which was significantly related to AOM concentration as displayed in Figure A.2), as shown in Table 5. However, most of the organic matter in the culture must have been retained within the microalgae culture by the ultrafiltration membranes (Liu et al., 2017; Luo et al., 2019), showing an effluent COD concentration of only $44 \pm 22 \mathrm{mg} \mathrm{COD} \cdot \mathrm{L}^{-1}$, which accomplished the legal requirements (Directive 91/271/CEE).

It should also be considered that AOM concentration in microalgae cultures tends to increase under stress (Lee et al., 2018), which can reduce microalgae activity. The culture age can also boost AOM in the culture (Henderson et al., 2008). In this respect, the normalisation of the sCOD with the microalgae biomass (sCOD:VSS) could be used as an indicator of the level of stress on the culture, since it would not include changes in 
sCOD due to microalgae growth (Appendix A). Significant increases of sCOD:VSS could favour heterotrophic bacteria growth (Galès et al., 2019; Luo et al., 2019) and in turn the growth of other superior organisms such as protozoa or rotifers, which can deteriorate the microalgae culture (Appendix B). As a result, significant inverse correlations were found between the sCOD:VSS ratio and NRR ( $\mathrm{p}$-value $<0.05 ; \mathrm{R}^{2}=$ $0.364 ; \mathrm{n}=16$ ) and biomass productivity ( $\mathrm{p}$-value $<0.05 ; \mathrm{R}^{2}=0.578 ; \mathrm{n}=20$ ), which confirms that the culture was negatively affected by stress. The NOx concentration and sCOD:VSS ratio can therefore be used to prevent microalgae culture deterioration.

On the other hand, $F_{v} / F_{m}$, which has been reported to be related to the efficiency of photosystem II (PSII) (Jebali et al., 2018), did not show any significant relationship with NRR and biomass productivity during the operating period, which indicates that $\mathrm{F}_{\mathrm{v}} / \mathrm{F}_{\mathrm{m}}$ does not seem an appropriate parameter to assess MPBR performance under these outdoor conditions.

\section{Conclusions}

Light path appears to be a key design factor since reducing it from 25 to $10 \mathrm{~cm}$ enhanced MPBR performance significantly. In fact, maximum NRR, PRR, biomass productivity and photosynthetic efficiency were obtained of $26.3 \pm 4.6 \mathrm{mg} \mathrm{N} \cdot \mathrm{L}^{-1} \cdot \mathrm{d}^{-1}$, $3.77 \pm 0.60 \mathrm{mg} \mathrm{P} \cdot \mathrm{L}^{-1} \cdot \mathrm{d}^{-1}, 258 \pm 20 \mathrm{mg} \mathrm{VSS} \cdot \mathrm{L}^{-1} \cdot \mathrm{d}^{-1}$ and $5.68 \pm 0.45 \%$, respectively. Moreover, the narrower MPBR light path raised light availability and decreased treatment costs.

Discharge limits were met when the 10-cm MPBR plant was operated at SRTs of 3-4.5 $\mathrm{d}$ and HRTs of 1.25-1.5 d, although nutrient recovery and photosynthetic efficiency were reduced when operated at 4.5-d SRT in comparison to 3-d SRT. When SRT was 
shortened to $2 \mathrm{~d}$ and HRT to $1 \mathrm{~d}$, MPBR performance decreased due to nitrifying and heterotrophic bacteria competing with microalgae.

The high VSS and sCOD concentrations obtained in the 10-cm MPBR plant forced it to operate at a transmembrane flux not higher than $15 \mathrm{LMH}$.

The ANOVA analysis showed that OD680 was an appropriate indicator of eukaryotic cell concentration, while sCOD concentration appeared as an indirect measurement of AOM concentration. Moreover, dissolved oxygen could be directly used as an indicator of MPBR performance, while $\mathrm{NO}_{\mathrm{x}}$ concentration and sCOD:VSS ratio could help prevent possible culture deteriorations since they were found to be inversely related to nitrogen recovery rates and biomass productivity.

\section{Acknowledgments}

This research work was supported by the Spanish Ministry of Economy and Competitiveness (MINECO, Projects CTM2014-54980-C2-1-R and CTM2014-54980C2-2-R) jointly with the European Regional Development Fund (ERDF), both of which are gratefully acknowledged. It was also supported by the Spanish Ministry of Education, Culture and Sport via a pre-doctoral FPU fellowship to authors J. GonzálezCamejo (FPU14/05082) and S. Aparicio (FPU/15/02595).

\section{E-supplementary data of this work (Appendix A, B and C) can be found in online version of the paper.}




\section{References}

1. APHA, 2012. Standard methods for the examination of water and wastewater, 22nd. American Public Health Association, American Water Works Association, Water Environment Federation, Washington, USA.

2. Arbib, Z., de Godos, I., Ruiz, J., Perales, J.A., 2017. Optimization of pilot high rate algal ponds for simultaneous nutrient removal and lipids production. Sci. Total Environ. 589, 66-72. http://dx.doi.org/10.1016/j.scitotenv.2017.02.206

3. Barceló-Villalobos, M., Fernández-del Olmo, P., Guzmán, J.L., FernándezSevilla, J.M., Acién Fernández, F.G., 2019. Evaluation of photosynthetic light integration by microalgae in a pilot-scale raceway reactor. Bioresour. Technol. 280, 404-411. https://doi.org/10.1016/j.biortech.2019.02.032

4. Day, J.G., Gong, Y., Hu, Q., Microzooplanktonic grazers, 2017. A potentially devastating threat to the commercial success of microalgal mass culture. Algal Res. 27, 356-365. http://dx.doi.org/10.1016/j.algal.2017.08.024

5. Fernández, I., Acién, F.G., Guzmán, J.L., Berenguel, M., Mendoza, J.L., 2016. Dynamic model of an industrial raceway reactor for microalgae production. Algal Res. 17, 67-78. http://dx.doi.org/10.1016/j.algal.2016.04.021

6. Fernández-Sevilla, J.M., Brindley, C., Jiménez-Ruíz, N., Acién, F.G., 2018. A simple equation to quantify the effect of frequency of light/dark cycles on the photosynthetic response of microalgae under intermittent light. Algal Res. 35, 479-487. https://doi.org/10.1016/j.algal.2018.09.026

7. Ferreira, G.F., Ríos Pinto, L.F., Maciel Filho, R., Fregolente, L.V., 2019. A review on lipid production from microalgae: Association between cultivation using waste streams and fatty acid profiles. Renew. Sust. Energy Rev. 109, 448466. https://doi.org/10.1016/j.rser.2019.04.052 
8. Galès, A., Bonnafous, A., Carré, C., Jauzein, V. Lanouguère, E., Le Floc'ha, E., Pinoit, J., Poullain, C., Roques, C., Sialve, B., Simier, M., Steyer, J.P., Fouilland, E., 2019. Importance of ecological interactions during wastewater treatment using High Rate Algal Ponds under different temperate climates, Algal Res. 40, 101508. https://doi.org/10.1016/j.algal.2019.101508

9. Gao, F., Cui, W., Xu, J.P., Li, C., Jin, W.H., Yang H.L., 2019. Lipid accumulation properties of Chlorella vulgaris and Scenedesmus obliquus in membrane photobioreactor (MPBR) fed with secondary effluent from municipal wastewater treatment plant. Renew. Energy 136, 671-676. https://doi.org/10.1016/j.renene.2019.01.038

10. Garrido-Cárdenas, J., Manzano-Agugliaro, F., Acién-Fernández, F.G., MolinaGrima, E., 2018. Microalgae research worldwide. Algal Res. 35, 50-60. https://doi.org/10.1016/j.algal.2018.08.005

11. González-Camejo, J., Barat, R., Aguado, D., Ferrer, J., 2020. Continuous 3-year outdoor operation of a flat-panel membrane photobioreactor to treat effluent from an anaerobic membrane bioreactor. Water Res. 169, 115238. https://doi.org/10.1016/j.watres.2019.115238

12. González-Camejo, J., Jiménez-Benítez, A., Ruano, M.V., Robles, A., Barat, R., Ferrer, J., 2019a. Optimising an outdoor membrane photobioreactor for tertiary sewage treatment. J. Environ. Manag. 245, 76-85. https://doi.org/10.1016/j.jenvman.2019.05.010

13. González-Camejo, J., Aparicio, A., Ruano, M.V., Borrás, L., Barat, R., Ferrer, J., 2019b. Effect of ambient temperature variations on an indigenous microalgae-nitrifying bacteria culture dominated by Chlorella. Bioresour. Technol. 290, 121788. https://doi.org/10.1016/j.biortech.2019.121788 
14. González-Camejo, J., Jiménez-Benítez, A., Ruano, M.V., Robles, A., Barat, R., Ferrer, J., 2019c. Preliminary data set to assess the performance of an outdoor membrane photobioreactor. Data in Brief 27, 104599. https://doi.org/10.1016/j.dib.2019.104599

15. Ferrer, J., Pretel, R., Durán, F., Giménez, J.B., Robles, A., Ruano, M.V., Serralta, Ribes, J., Seco, A., 2015. Design methodology for submerged anaerobic membrane bioreactors (AnMBR): A case study. Sep. Purif. Technol. 141, 378-386. http://dx.doi.org/10.1016/j.seppur.2014.12.018

16. Henderson, R.K., Baker, A., Parsons, S.A., Jefferson, B., 2008. Characterisation of algogenic organic matter extracted from cyanobacteria, green algae and diatoms. Water $\quad$ Res. $\quad$ 42(13), 3435-3445. https://doi.org/10.1016/j.watres.2007.10.032

17. Huang, J., Hankame, B., Yarnold, J., 2019. Design scenarios of outdoor arrayed cylindrical photobioreactors for microalgae cultivation considering solar radiation and temperature. Algal Res. 41, 101515. https://doi.org/10.1016/j.algal.2019.101515

18. Iasimone, F., De Felice, V., Panico, A., Pirozzi, F., 2017. Experimental study for the reduction of $\mathrm{CO}_{2}$ emissions in wastewater treatment plant using microalgal cultivation. J. $\mathrm{CO}_{2}$ Util. 22, 1-8. http://dx.doi.org/10.1016/j.jcou.2017.09.004

19. Jebali, A., Acién, F.G., Rodriguez Barradas, E., Olguín, E.J., Sayadi, S., Molina Grima, E., 2018. Pilot-scale outdoor production of Scenedesmus sp. in raceways using flue gases and centrate from anaerobic digestion as the sole culture $\begin{array}{llll}\text { medium. } & \text { Bioresour. } & \text { Technol. } & \text { 262, }\end{array}$ https://doi.org/10.1016/j.biortech.2018.04.057 
20. Judd, S., van den Broeke, L.J.P., Shurair, M., Kuti, Y., Znad, H., 2015. Algal remediation of $\mathrm{CO}_{2}$ and nutrient discharges: a review. Water Res. 87, 356-366. http://dx.doi.org/10.1016/j.watres.2015.08.021

21. Lee, J.C., Baek, K., Kim, H.W., 2018. Semi-continuous operation and fouling characteristics of submerged membrane photobioreactor (SMPBR) for tertiary treatment of livestock wastewater. J. Clean. Prod. 180, 244-251. https://doi.org/10.1016/j.jclepro.2018.01.159

22. Liu, B., Qu, F., Liang, H., Gan, Z., Yu, H., Li, G., Van der Bruggen, B., 2017. Algae-laden water treatment using ultrafiltration: Individual and combined fouling effects of cells, debris, extracellular and intracellular organic matter. J. Membr. Sci. 528, 178-186. https://doi.org/10.1016/j.memsci.2017.01.032

23. Luo, Y., Henderson, R.K., Le-Clech, P., 2019. Characterisation of organic matter in membrane photobioreactors (MPBRs) and its impact on membrane $\begin{array}{llll}\text { performance. } & \text { Algal } & \text { Res. } & 44,\end{array}$ https://doi.org/10.1016/j.algal.2019.101682

24. Luo, Y., Le-Clech, P., Henderson, R.K., 2018. Assessment of membrane photobioreactor (MPBR) performance parameters and operating conditions. Water Res. 138, 169-180. https://doi.org/10.1016/j.watres.2018.03.050

25. Norsker, N.H., Barbosa, M.J., Vermuë, M.H., Wijffels, R.H., 2011. Microalgal production - A close look at the economics. Biotech. Adv. 29, 24-27. http://dx.doi.org/10.1016/j.biotechadv.2010.08.005

26. Nwoba, E.G., Parlevliet, D.A., Laird, D.W., Alameh, K., Moheimani, N.R., 2019. Light management technologies for increasing algal photobioreactor efficiency. Algal Res. 39, 101433. https://doi.org/10.1016/j.algal.2019.101433 
27. Razzak, S.A., Ali, S.A.M., Hossain, M.M., deLasa, H., 2017. Biological $\mathrm{CO}_{2}$ fixation with production of microalgae in wastewater - A review. Renew. Sust. Energy Rev. 76, 379-390.http://dx.doi.org/10.1016/j.rser.2017.02.038

28. Romero-Villegas, G.I., Fiamengo, M., Acién-Fernández, F.G., Molina-Grima, E., 2018. Utilization of centrate for the outdoor production of marine microalgae at the pilot-scale in raceway photobioreactors, J. Environ. Manag. 228, 506-516. https://doi.org/10.1016/j.jenvman.2018.08.020

29. Romero-Villegas, G.I., Fiamengo, M., Acién-Fernández, F.G., Molina-Grima, E., 2017. Outdoor production of microalgae biomass at pilot-scale in seawater using centrate as the nutrient source. Algal Res. 25, 538-548. http://dx.doi.org/10.1016/j.algal.2017.06.016

30. Rossi, S., Bellucci, M., Marazzi, F., Mezzanotte, V., Ficara, E., 2018. Activity assessment of microalgal-bacterial consortia based on respirometric tests. Water Sci Technol. 78(1-2), 207-215. https://doi.org/10.2166/wst.2018.078

31. Ruiz, J., Arbib, Z., Álvarez-Díaz, P.D., Garrido-Pérez, C., Barragán, J., Perales, J.A., 2014. Influence of light presence and biomass concentration on nutrient kinetic removal from urban wastewater by Scenedesmus obliquus. J. Biotechnol. 178, 32-37. http://dx.doi.org/10.1016/j.jbiotec.2014.03.001

32. Seco, A., Aparicio, S., González-Camejo, J., Jiménez-Benítez, A., Mateo, O., Mora, J.F., Noriega-Hevia, G., Sanchis-Perucho, P., Serna-García, R., Zamorano-López, N., Giménez, J.B., Ruiz-Martinez, A., Aguado, D., Barat, R., Borrás, L., Bouzas, A., Martí, N., Pachés, M., Ribes, J., Robles, A., Ruano, M.V., Serralta, J. and Ferrer, J., 2018. Resource recovery from sulphate-rich sewage through an innovative anaerobic-based water resource recovery facility 
$\begin{array}{llllll}\text { (WRRF). } & \text { Water } & \text { Sci. } & \text { Technol. } & 78 & \text { (9), }\end{array}$ https://doi.org/10.2166/wst.2018.492

33. Sepúlveda, C., Acién, F.G., Gómez, C., Jiménez-Ruíz, N., Riquelme, C., Molina-Grima, E., 2015. Utilization of centrate for the production of the marine microalgae Nannochloropsis gaditana, Algal Res. 9, 107-116. http://dx.doi.org/10.1016/j.algal.2015.03.004

34. Slegers, P.M., Wijffels, R.H., van Straten, G., and van Boxtel, A.J.B., 2011. Design scenarios for flat panel photobioreactors. Appl. Energ. 88(10), 33423353. https://doi.org/10.1016/j.apenergy.2010.12.037

35. Solovchenko, A., Khozin-Goldberg, I., Selyakh, I., Semenova, L., Ismagulova, T., Lukyanov, A., Mamedov, I., Vinogradova, E., Karpova, O., Konyukhov, I., Vasilieva, S., Mojzes, P., Dijkema, C., Vecherskaya, M., Zvyagin, I., Nedbal, L., Gorelov, O., 2019. Phosphorus starvation and luxury uptake in green microalgae revisited. Algal Res. 43, 101651. https://doi.org/10.1016/j.algal.2019.101651

36. Thomas, P.K., Dunn, G.P., Good, A.R., Callahan, M.P., Coats, E.R., Newby, D.T., Feris, K.P., 2019. A natural algal polyculture outperforms an assembled polyculture in wastewater-based open pond biofuel production. Algal Res. 40, 101488. https://doi.org/10.1016/j.algal.2019.101488

37. Viruela, A., Robles, A., Durán, F., Ruano, M.V., Barat, R., Ferrer, J., Seco, A., 2018. Performance of an outdoor membrane photobioreactor for resource recovery from anaerobically treated sewage. J. Clean. Prod. 178, 665-674. https://doi.org/10.1016/j.jclepro.2017.12.223

38. Xu, X., Gu, X., Wang, Z., Shatner, W., Wang, Z., 2019. Progress, challenges and solutions of research on photosynthetic carbon sequestration efficiency of 
microalgae. Renew. Sust. Energy Rev. 110, 65-82.

https://doi.org/10.1016/j.rser.2019.04.050 